\title{
FLORA DA SERRA DO CIPÓ, MINAS GERAIS: BROMELIACEAE - TILLANDSIOIDEAE ${ }^{1}$
}

\author{
JOÃO VICENTE COFFANI-NUNES*, LEONARDO M. VERSIEUX**, MARIA DAS GRAÇAS \\ LAPA WANDERLEY** \& JOSÉ RUBENS PIRANI***
}

\author{
*Universidade Estadual Paulista, Unidade Diferenciada de Registro, Av. Nelson Brihi Badur 430, 11900-000 - Registro, SP, Brasil. \\ **Instituto de Botânica, Caixa postal 3005, 01061-970 - São Paulo, SP, Brasil. \\ ***Departamento de Botânica, Instituto de Biociências, Universidade de São Paulo, Rua do Matão 277, 05508-900 - São Paulo, SP, Brasil.
}

\begin{abstract}
Flora of the Serra do Cipó, Minas Gerais: Bromeliaceae - Tillandsioideae). The taxonomic treatment of Tillandsioideae (Bromeliaceae) for the project "Flora of Serra do Cipó, Minas Gerais, Brasil" is presented. The subfamily is represented in the study area by four genera and 24 species: Alcantarea (2 species), Racinaea (1 species), Tillandsia (9 species) and Vriesea (12 species). Descriptions and illustrations as well as comments on the taxonomy, geographic distribution, phenology, and keys to genera and species are presented. A new synonym, Vriesea monacorum L.B.Sm., is considered under the concept of V. schwackeana Mez. Alcantarea hatschbachii is rediscovered.
\end{abstract}

Resumo - (Flora da Serra do Cipó, Minas Gerais, Brasil: Bromeliaceae - Tillandsioideae). Apresenta-se o tratamento taxonômico de Tillandsioideae (Bromeliaceae) para o projeto "Flora da Serra do Cipó, Minas Gerais, Brasil". A subfamília está representada na área de estudo por quatro gêneros e 24 espécies: Alcantarea (2 espécies), Racinaea (1 espécie), Tillandsia (9 espécies) e Vriesea (12 espécies). São apresentadas chaves para gêneros e espécies, descrições e ilustrações, bem como comentários sobre a taxonomia, distribuição geográfica e fenologia. Propõe-se a sinonimização de Vriesea monacorum L.B.Sm. sob V. schwackeana Mez. Alcantarea hatschbachii é redescoberta.

Key words: Tillandsioideae, Bromeliaceae, campo rupestre, Serra do Cipó, Minas Gerais.

\section{Tillandsioideae Harms}

Plantas herbáceas, epífitas, rupícolas ou terrestres. Folhas em roseta ou distribuídas ao longo do caule; margens lisas, indumento de escamas radialmente simétricas. Ovário geralmente súpero, raramente semi-ínfero ou ínfero. Fruto cápsula septicida; sementes estreitas com apêndices plumosos na base e/ou no ápice.
A subfamília Tillandsioideae inclui alguns dos maiores gêneros de Bromeliaceae. Abrange quatro tribos: Catopsideae: Catopsis; Glomeropitcairnieae: Glomeropitcairnia; Vrieseeae: Alcantarea, Vriesea, Werauhia; Tillandsieae: Guzmania, Mezobromelia, Racinaea, Tillandsia e Viridantha (Barfuss et al. 2005).

Bibliografia básica: Smith \& Downs (1974, 1977), Reitz (1983), Till (2000).

\section{Chave para os gêneros}

1. Pétalas com 2 apêndices petalíneos na base da face interna.

2. Pétalas longo-lineares, maiores que $6.5 \mathrm{~cm}$, apêndices plumosos apicais e basais desenvolvidos na semente. 1. Alcantarea

2'. Pétalas oblongas, elípticas ou obovais, menores que $6 \mathrm{~cm}$, apêndices plumosos apicais atrofiados e os basais desenvolvidos na semente.

1'. Pétalas sem apêndices petalíneos na base da face interna.

3. Folhas esparsamente lepidotas, verdes com máculas roxas, formando tanque em forma de utrículo

3'. Folhas densamente recobertas por escamas cinéreas, roseta sem formar tanque ou tanque inconspícuo

4. Folhas maiores que $60 \mathrm{~cm}$ compr.; sépala maior ou igual a $3 \mathrm{~cm}$ compr. e $1,1 \mathrm{~cm}$ larg

\footnotetext{
${ }^{1}$ Trabalho realizado conforme o planejamento apresentado por Giulietti et al. (1987). A descrição da família Bromeliaceae na série Flora da Serra do Cipó foi apresentada por Forzza \& Wanderley (1998).
} 


\section{Alcantarea (E. Morren ex Mez) Harms}

Rupícolas, perenes; caule curto e inconspícuo ou robusto e coberto pelas bainhas foliares. Roseta em geral formando tanque, infundibuliforme. Folhas em geral liguladas ou lanceoladas, distintamente divididas entre lâmina e bainha. Escapo robusto ou delgado, ereto ou subereto, coberto por brácteas vistosas divergentes, algumas vezes imbricadas. Inflorescência simples ou composta, multiflora; pedúnculos laterais geralmente bracteados. Flores vistosas, dísticas ou secundas, sésseis; pétalas frequentemente amarelas, raro alvacentas ou vinoso-amareladas, efêmeras, lineares, ca. 9 vezes mais longas do que largas, ápice agudo a obtuso, tornando-se espiraladas, fortemente recurvadas para trás ou flácidas e com coloração mais clara logo após a antese, em geral com 2 apêndices petalíneos basais; estames e estilete em geral exsertos, livres; ovário semi-ínfero. Sementes com apêndices plumosos no ápice e na base.

O gênero reúne espécies rupícolas que ocorrem em inselbergs do leste do Brasil e, mais raramente, em campo rupestre, na Cadeia do Espinhaço.

\section{Chave para as espécies}

1. Lâminas foliares 1-1,6 cm larg., densamente lepidotas; roseta pouco desenvolvida; inflorescência simples (raramente com uma pequena ramificação na base); pétalas nuas 1.1. A. hatschbachii

1'. Lâminas foliares 7,5-11 cm larg., glabrescentes; roseta bem desenvolvida; inflorescência composta (ramificada); pétalas com apêndices petalíneos 1.2. A. turgida

1.1. Alcantarea hatschbachii (L.B.Sm. \& Read) Leme, Bromélia 2(3): 22. 1995.

Fig. 1 A; 6 A-B

Rupícola, 0,8-1,4 m compr. Folhas suberetas, 60-70 cm compr.; bainha 9-11 cm compr., 2-4 cm larg., estreito-elíptica; lâmina 50-60 cm compr., 1-1,6 cm larg., linear, ápice agudo, verde-clara. Escapo 0,5-1 m compr., ereto, delgado, verde. Bráctea do escapo 3,4-25 cm compr., 1-2,3 cm larg., base estreito-oval, lâmina linear-triangular, ápice longo-caudado a acuminado, verde. Inflorescência $15-30 \mathrm{~cm}$ compr., 3-4 $\mathrm{cm}$ larg. (excluindo as pétalas), espiga, raramente com uma pequena ramificação basal, reta a levemente encurvada. Bráctea floral 2,9-4 cm compr., 1,6-2,3 cm larg., oval a largo oval, ápice obtuso. Flores dísticas passando a secundas; sépalas 3-3,2 cm compr., ca. 1,1 cm larg., elípticas, ápice obtuso, verdes; pétalas ca. $6,5 \mathrm{~cm}$ compr., ca. $0,8 \mathrm{~cm}$ larg., liguladas, ápice agudo, amarelo claro esverdeadas; apêndices petalíneos ausentes; estames imaturos ca. 4,5 cm compr.; estilete imaturo ca. $4 \mathrm{~cm}$ compr. Cápsulas e sementes desconhecidas.

Material examinado: Minas Gerais, Santana de Pirapama, Serra do Cipó, D. C. Zappi et al. 2599, 24.XI.2009, fl. (SP, SPF).

Material adicional examinado: Minas Gerais, Gouveia, rodovia BR259, encosta rochosa de morro, Hatschbach et al. 29085, 21.I.1972, fr. passado (MBM, SPF, US, Z); rodovia BR-259, $10 \mathrm{~km} \mathrm{~S}$ de Gouveia, Hatschbach 40820, 22.I.1978, fl. (MBM).

Alcantarea hatschbachii era conhecida apenas de duas coleções, ambas do município de Gouveia, Minas Gerais. O registro desta espécie na Serra do Cipó é de extrema importância, uma vez que ela vinha sendo considerada como extinta por alguns autores. A recente redescoberta de populações desta espécie na porção norte da Serra do Cipó possibilita que se amplie a caracterização morfológica e o conhecimento da sua distribuição geográfica. Inicialmente tratada como uma espécie que só apresentava inflorescência simples, os novos materiais indicam que pode haver ao menos uma ramificação pequena na base da espiga. Apesar da obra original mencionar que a inflorescência é dística, no isótipo do SPF assim como a coleção Hatschbach 40820 e nas fotos do material recém coletado na Serra do Cipó (Zappi 2599), observa-se que os botões florais são dísticos mas que as flores maduras são distintamente secundas. Foi coletada com flores em novembro.

1.2. Alcantarea turgida Versieux \& Wand., Brittonia 59(1): 58. 2007.

Fig. 1 B-I; 6 C

Rupícola, 1,1-2,5 m compr. Folhas suberetas; bainha 1927 compr., 8-19 cm larg., largo-oval; lâmina 61-75 cm compr., 7,5-11 cm larg., ligulada, ápice agudo a cuspidado, verde a verde-vinosa. Escapo $80-120 \mathrm{~cm}$ compr., ereto, robusto, verde a vinoso. Bráctea do escapo 2,2-5,5(-22) compr., 3,5$5,5 \mathrm{~cm}$ larg., oval, ápice longo-caudado, mucronado, verde maculada de vermelho-vinoso ou vinosa. Inflorescência 0,61,3 m compr., 0,7-1 m diâm., composta. Bráctea primária largamente oval, mais curta que base estéril do pedúnculo lateral; ramos da inflorescência 14-32, (3-)10-18 flores por ramo; ráquila $18-27 \mathrm{~cm}$ compr., geniculada; bráctea floral 3,4-3,7 cm compr., 3,6-4(-4,4) cm larg., suborbicular, ápice obtuso discretamente mucronado. Flores dísticas; sépalas 3,64(-4,4) cm compr., 1,4-1,8 cm larg., obovadas, ápice agudo e minutamente apiculado, verdes a verde-amareladas com ápice geralmente vinoso; pétalas 9-11 cm compr., 1-1,3 cm larg., liguladas, ápice agudo, amarelas passando à amareloalvacentas; apêndices petalíneos 34-37 mm compr., ligulados; estames 9-10 cm compr.; estilete 9,3-10 cm compr. Cápsula 5,3-6,2 cm compr., ca. $1 \mathrm{~cm}$ diâm.

Material examinado: Minas Gerais, Conceição do Mato Dentro, alto da cachoeira do Tabuleiro, L.M. Versieux et al. 260, 22.XII.2005, fl. (BHCB, SP, SPF). Santana do Riacho, 
cultivada no jardim do Parque Nacional da Serra do Cipó, L.M. Versieux et al. 157, 6.I.2004, fl. (SP); Parque Nacional da Serra do Cipó, afloramento em frente à portaria do Condomínio Solar do Palácio, M.G.L. Wanderley et al. 2488, 11.XII.2005, bt. (SP); ibidem, L.M. Versieux et al. 300, 8.X.2006, fr. (SP); Rodovia Belo Horizonte-Conceição do Mato Dentro, afloramento rochoso próximo à bifurcação para Morro do Pilar, L.M. Versieux et al. 474, 25.IV.2009, fr. (SP, SPF).

Material adicional examinado: Minas Gerais, São Gonçalo do Rio Abaixo, Estação Ambiental de Peti CEMIG, J.A. Lombardi et al. 4748, 23.IV.2002, fr. (BHCB, RFA). Itabira, A.M. Matos s.n., VI.1902, fl. (R 46318).

Em geral são plantas utilizadas em jardins e dentro do Parque Nacional Serra do Cipó já foram apreendidos exemplares desta espécie coletados ilegalmente para tal finalidade (IBAMA, com. pess.). Alcantarea turgida é uma espécie muito próxima de Alcantarea extensa (L.B.Sm.) J.R. Grant e pode ser vista nas porções mais elevadas das vertentes orientais da Serra do Cipó e em grandes populações nos paredões da cachoeira do Tabuleiro, em Conceição do Mato Dentro, onde é possível ver indivíduos com folhas totalmente verdes ou vinosas (Figura $6 \mathrm{C}$ ). Floresce de dezembro a janeiro.

\section{Racinaea M. A. Spencer \& L. B. Sm.}

Epífitas, perenes; caule geralmente curto. Roseta utriculosa. Folhas pouco numerosas a numerosas; bainha conspícua; lâmina verde a cinérea, algumas vezes com máculas, ligulada, lanceolada ou estreito-triangular, lepidota. Escapo ereto ou recurvado; brácteas lepidotas. Inflorescência simples ou composta, multiflora. Brácteas florais verdes, em geral pouco vistosas. Flores dísticas, sésseis a curto-pediceladas; sépalas livres ou conatas na base, largo-elípticas, assimétricas; pétalas amarelas ou alvas, apêndices petalíneos ausentes; estames e pistilo inclusos; ovário súpero. Sementes com apêndices plumosos na base.

\subsection{Racinaea aeris-incola (Mez) M.A.Spencer \&} L.B.Sm., Phytologia 74(2): 153. 1993.

Fig. $1 \mathrm{~J}$
Epífita, 30-35 cm compr. Roseta utriculosa. Folhas 10-18 cm compr., 0,5-1,1 cm larg.; bainha 3-5 cm larg., suborbicular; lâmina estreito-triangular, ápice longoatenuado, com manchas ou faixas purpúreas ou castanhoavermelhadas. Brácteas do escapo 1,5-3 cm compr., 0,6-0,8 cm larg., mais curtas que os entrenós, oval-lanceoladas, ápice agudo a aristado. Inflorescência 12-15 cm compr., composta, 5-7 espigas, cada uma 8-14-flora, recurvada, raque exposta, flexuosa a geniculada. Brácteas primárias ca. $1 \mathrm{~cm}$ compr., semelhantes às brácteas do escapo. Brácteas florais ca. $4 \mathrm{~mm}$ compr., ovais. Flores sésseis; sépalas 4-5 mm compr., ovais, ápice agudo, ecarenadas; pétalas mais curtas que as sépalas, ca. $2 \mathrm{~cm}$ larg., largamente ovais. Cápsula ca. $25 \mathrm{~cm}$ compr.

Material examinado: Conceição do Mato Dentro, Parque Natural Municipal do Ribeirão do Campo, R.C. Mota \& P.L. Viana 1834, 7.VII.2002, fr. (BHCB).

Material adicional examinado: São Paulo, São Luiz do Paraitinga, Parque Estadual da Serra do Mar, G. Martinelli et al. 15915, X.1999, fr. (RB, SP).

Espécie de fácil reconhecimento pelo formato dilatado da base da roseta e pelas folhas levemente enrugadas e com máculas arroxeadas. Ocorre desde o Espírito Santo até Santa Catarina e, na Serra do Cipó, apesar de ser comumente observada em estado vegetativo nos capões de mata do Alto do Palácio, só há um registro na região de Conceição do Mato Dentro. Frutifica em julho.

\section{Tillandsia L.}

Epífitas ou rupícolas. Caule pouco a bem desenvolvido. Folhas em roseta sem formar tanque, ou distribuídas ao longo do caule, polísticas ou dísticas; lâminas filiformes a estreitamente triangulares, lepidotas em ambas as faces. Escapo delgado. Inflorescência simples ou composta, racemos, espigas ou, mais raramente, reduzida a uma única flor. Bráctea floral conspícua a diminuta. Flores com pedicelos curtos ou sésseis; sépalas simétricas a assimétricas, livres ou conatas; pétalas livres, sem apêndices petalíneos na base; estames de comprimentos variados em relação às pétalas e ao pistilo; ovário súpero, glabro; óvulos numerosos, caudados. Sementes com apêndices plumosos na base.

\section{Chave para as espécies}

1. Folhas filiformes, até $1 \mathrm{~mm}$ de diâm.

2. Caule pendente; entrenós com mais de 1,5 cm compr.; escapo e raízes ausentes 3.9. T. usneoides

2'. Caule ereto; entrenós com menos de $1 \mathrm{~cm}$ compr.; escapo e raízes presentes 3.4. T. recurvata

1'. Folhas estreito- ou linear-triangulares, com mais de $2 \mathrm{~mm}$ larg. próximo à base da lâmina foliar.

3. Base da lâmina com 2-4 mm de larg.

4. Caule desenvolvido com folhas distribuídas em toda sua extensão 3.8. T. tricholepis

4'. Caule curto com folhas formando roseta 3.3. T. loliacea

3'. Base da lâmina com mais de $5 \mathrm{~mm}$ de larg. 
5. Brácteas do escapo e brácteas florais dísticas

3.5. T. streptocarpa

5 '. Brácteas do escapo e brácteas florais polísticas.

6. Inflorescência simples (sem ramos laterais).

7. Caule curto, folhas formando roseta; brácteas do escapo e floral com escamas na região distal

3.6. T. stricta

7'. Caule alongado, geralmente pendente; folhas distribuídas ao longo do caule; brácteas do escapo e floral glabras na região distal 3.7. T. tenuifolia

6'. Inflorescência composta (ramificada).

8. Inflorescência globosa; bráctea floral maior que as sépalas e com indumento denso, cinéreo .... 3.1. T. gardneri 8'. Inflorescência sub-piramidal; bráctea floral menor que as sépalas e esparsamente lepidotas 3.2. T. geminiflora

3.1. Tillandsia gardneri Lindl., Edward's Bot. Reg. 28: $t$. 63. 1842.

Fig. $1 \mathrm{~K}-\mathrm{Q}$

Epífita, 11-33 cm compr.; caule reduzido. Folhas 7,2$33,5 \mathrm{~cm}$ compr., 0,9-1,8 cm larg., linear-triangulares, em roseta, densamente lepidotas, escamas ultrapassando o limite da margem da lâmina foliar, folhas senis marcescentes e reflexas. Escapo 9-12 cm compr. Bráctea do escapo 2,2-7,6 cm compr., 0,5-1 cm larg., linear-triangular ou oval-aristada. Inflorescência 3,7-7 cm compr., composta, globosa, ereta a subereta, densa. Bráctea primária 1,6-4,2 cm compr., 0,5-1,1 $\mathrm{cm}$ larg., elíptica ou oval, acuminada ou aristada. Bráctea floral 1,2-1,8 cm compr., 0,4-0,8 cm larg., elíptica, aguda, lepidota, carenada. Flores polísticas; sépala ca. $1,1 \mathrm{~cm}$ compr., ca. $5 \mathrm{~mm}$ larg., oval, ápice agudo, carenada; pétala ca. $1,5 \mathrm{~cm}$ compr., ca. $3 \mathrm{~mm}$ de larg., ligulada; estames livres; estilete mais longo que o ovário Cápsula ca. $2 \mathrm{~cm}$ compr.

Material examinado: Minas Gerais, Conceição do Mato Dentro, Parque Natural Municipal do Ribeirão do Campo, R.C. Mota \& P.L. Viana 1837, 1.VIII.2002, fl. (BHCB). Santana do Riacho, Parque Nacional da Serra do Cipó, km 135, M.L. Kawasaki et al. CFSC 9142 in part, 5.XI.1983, fr. (SPF); Congonhas, M.G.L. Wanderley et al. CFSC 11531, 21.V.1989, fl. (SP); $400 \mathrm{~m}$ antes da bifurcação Conceição - Morro do Pilar, M.T.V. Campos CFSC 13730, 23.V.1993, bt. (SPF); idem, M.T.V. Campos CFSC 13521, 20.XI.1993, fr. (SPF). Serra do Cipó, $L$. Damasio s.n., s.d., fr. (OUPR 13873).

Vegetativamente, T. gardneri é confundida com $T$. geminiflora pela presença de folhas senis marcescentes e reflexas na roseta. Contudo, são facilmente diferenciadas pela inflorescência densa e globosa, com ramos curtos e a raque ocultada pelas brácteas primárias em T. gardneri, enquanto em $T$. geminiflora a inflorescência é sub-piramidal com ramos alongados, expondo a raque, pelo menos na porção inferior. Além disso, as folhas são densamente lepidotas, com escamas ultrapassando o limite da lâmina em T. gardneri, não sendo observada esta característica em $T$. geminiflora, que também possui folhas lepidotas, porém em menor densidade. Na Serra do Cipó, T. gardneri foi encontrada em flor nos meses de abril, maio e agosto.

3.2. Tillandsia geminiflora Brongn., Voy. Monde, Phan. 186. 1834.

Fig. 1 R-Z.
Epífita, 12-23 cm compr.; caule curto. Folhas 6,3-18,5 $\mathrm{cm}$ compr., 0,6-1,6 cm larg., linear-triangulares, verde-claras, em roseta, densamente lepidotas, escamas não ultrapassando o limite da lâmina, marcescentes e reflexas quando senis. Escapo 7-15,5 cm compr. Bráctea do escapo 3-9,1 cm compr., 0,6-1 cm larg., oval ou elíptica, aristada ou acuminada. Inflorescência 4.5-9 cm compr., composta, sub-piramidal, com ramos proximais mais alongados expondo a raque, ereta. Bráctea primária 1,2-7,7 cm compr., 0,5-1,1 cm larg., oval ou elíptica, aristada ou acuminada. Bráctea floral 0,61,3 cm compr., 0,3-0,6 cm larg., oval a elíptica, apiculada ou acuminada, carenada. Flores polísticas; sépalas 1,2-1,6 cm compr., 0,2-0,3 cm larg., elípticas ou ovais, acuminadas a mucronadas, carenadas, a posterior unida na base às duas anteriores, estas unidas até a região mediana; pétalas ca. 1,7 cm compr., 0,3-0,4 cm larg., estreitamente elípticas, obtusas, róseas a lilás, unidas até a região mediana. Estames do segundo verticilo epipétalos; estilete ca. $1 \mathrm{~cm}$ compr., estigma ereto, retorcido, papiloso, exserto. Cápsula 2,5-3,5 cm compr.

Material examinado: Minas Gerais, Conceição do Mato Dentro, Parque Natural Municipal do Ribeirão do Campo, R.C. Mota \& L.M. Versieux 1840, 13.IX.2002, fl. (BHCB). Jaboticatubas, Serra do Cipó, estrada da Usina, M.G.L. Wanderley CFSC 5573, 16.VIII.1979, fl. (SP). Santana do Riacho, Serra do Cipó, Rodovia Belo Horizonte-Conceição do Mato Dentro, km 123, M.G. Arrais CFSC 9171, 17.VII.1983, fl. (SPF); km 132, M.G. Arrais CFCR 6058, 15.XI.1984, fr. (SPF); próximo a estátua do Velho Juquinha, km 124, J.V. Coffani-Nunes 1, 13.VI.1992, fl., fr. (SPF); Parque Nacional Serra do Cipó, J.V. Coffani-Nunes $3 a$, 14.VI.1992, fl. (SPF); Serra do Cipó, J.V. Coffani-Nunes 39, 2.V.1993, fl. (SPF); Serra do Cipó, ca. 1300 m.s.m., M.F. Vasconcelos s.n., 20.I.1998, fl. (BHCB 40115); mata do Juquinha, L.M. Versieux \& P.M. Elbl 489, 26.IV.2009, fr. (SP). Serra do Cipó, (córrego) Vacaria, M.B. Foster \& $R$. Foster 616, 12.VII.1940, fl., fr. (SP).

Espécie bem delimitada, mas como referido anteriormente, assemelha-se a T. gardneri. Apresenta duas variedades, sendo a típica encontrada na Serra do Cipó e T. geminiflora var. incana (Wawra) Mez, conhecida para a região do Estado do Rio de Janeiro ao Uruguai e diferenciada da variedade típica pela menor densidade de tricomas (Smith \& Downs 1977). Apresenta dois picos de floração durante o ano, um em junho e outro em novembro. A dispersão das sementes é anemocórica, no entanto, eventualmente elas permanecem aderidas à infrutescência, germinam e, posteriormente, caem fixando-se ou não no tronco do forófito. 


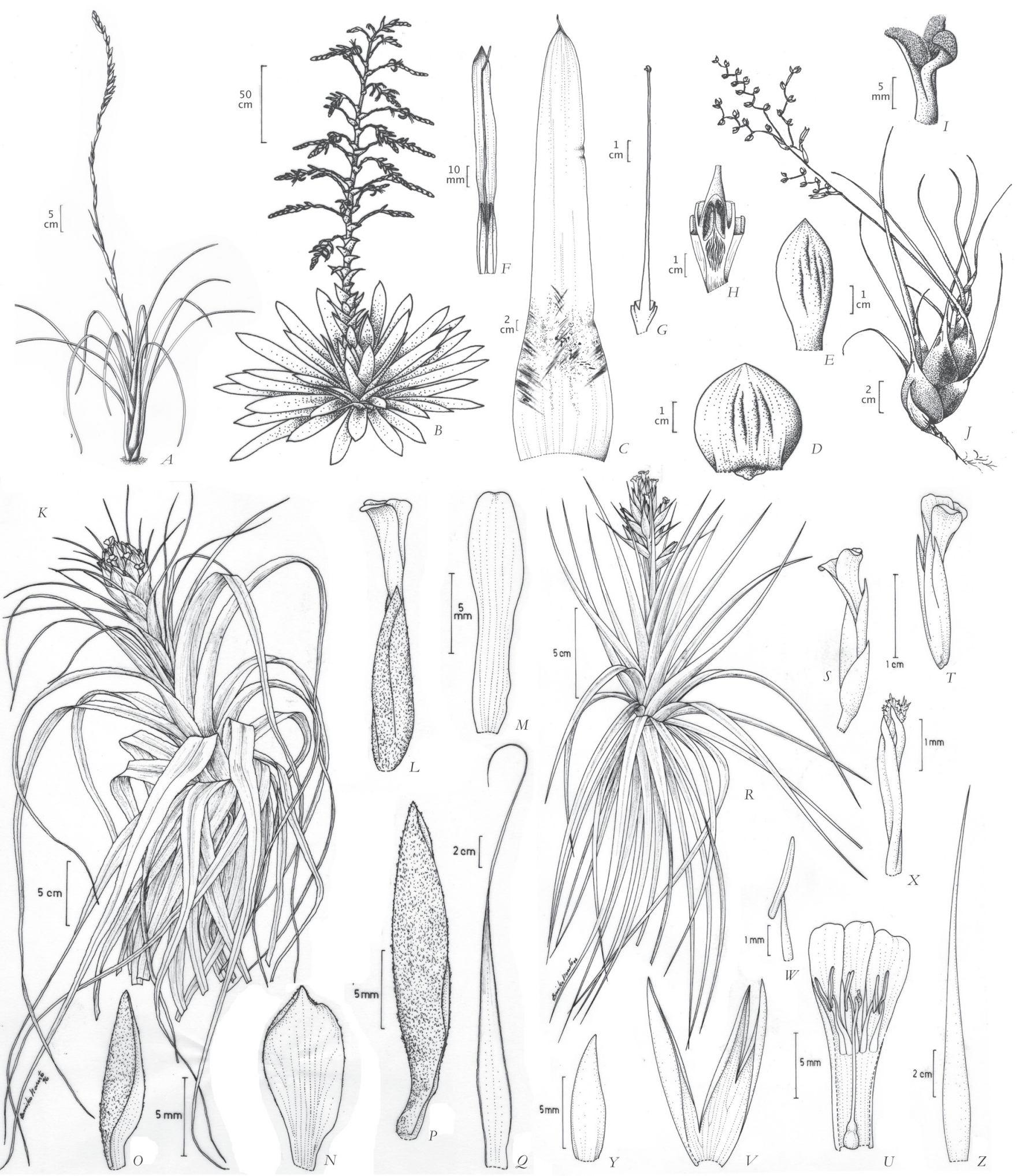

Fig. 1. A. Alcantarea hatschbachii, hábito. B-I. Alcantarea turgida. B. Hábito, C. Folha, D. Bráctea floral, E. Sépala, F. Pétala, G. Pistilo, H. Ovário, I. Estigma. J. Racinaea aeris-incola. Hábito. K-Q. Tillandsia gardneri. K. Hábito, L. Flor, M. Pétala, N. Sépala, O. Bráctea floral, P. Bráctea primária, Q. Folha. R-Z. T. geminiflora. R. Hábito, S-T. Flor, U. Flor aberta, V. Sépalas, W. Antera, X. Estigma, Y. Bráctea floral, Z. Folha. [A. Hatschbach 40820, B-I. Versieux 260, J. Martinelli 15915, K-Q. CFSC 13730, R-Z. Coffani-Nunes 3]. 
3.3. Tillandsia loliacea Mart. ex Schult. \& Schult. f. in J.J. Roemer \& J.A. Schultes, Syst. veg. 7(2): 1204. 1830.

Fig. $2 \mathrm{~A}$

Epífita ou rupícola, 4-12 cm compr.; caule curto. Folhas 1,5-3,5 cm compr., 3-4 mm larg., rosuladas, polísticas, eretas a suberetas, densamente lepidotas; bainha largo-oval; lâmina cinérea, involuta, estreito-triangular, ápice longo-atenuado. Escapo 3.5-6 cm compr. Bráctea do escapo 8-14 mm compr., 2-3 mm larg., lanceolada, conduplicada, imbricada, densamente lepidota. Inflorescência 1.3-2.5 cm compr., simples, 3-7-flora, linear; raque fortemente geniculada. Bráctea floral 6-10 mm compr., 3-4 mm larg., oblongoelípticas, ápice agudo, verde-acinzentada, igualando-se ou menor que as sépalas, densamente lepidota. Flores dísticas; sépalas 5-9 mm compr., ca. $2 \mathrm{~mm}$ larg., lanceoladas, ápice agudo, glabras, livres; pétalas 7-8 mm compr., liguladas, ápice agudo amarelas; estames livres, inclusos; estilete espesso, mais curto que o ovário. Cápsula ca. $5 \mathrm{~cm}$ compr.

Material examinado: Minas Gerais, Jaboticatubas, distrito de São José da Serra, Serra do Cipó, 19²6’45.3”S, 4337'52.2”W, 774 m.s.m., L.M. Versieux et al. 476, 25.IV.2009, fr. (SP). Santana do Riacho, Condomínio Rio Cipó, Serra do Cipó, A. Costa et al. 74, 3.II.1987, fr. (RB); morro da Pedreira, G.A.S. Castro s.n., 21.IV.1990, fr. (BHCB 17591); morro da Pedreira ( ${ }^{\circ}$ grupo), fazenda Canto da Serra, J.R. Pirani et al. CFSC 13267, 22.VII.1993, fr. (SPF).

Material adicional examinado: São Paulo, Iperó, J.Y. Tamashiro 454, fl. VIII.1994, (SP).

Espécie de ampla distribuição, ocorre do Nordeste ao Sul do Brasil, estendendo-se para a Argentina, chegando à Bolívia e Paraguai. Na Serra do Cipó ocorre principalmente nas áreas de menor altitude, como nos afloramentos calcários da região do morro da Pedreira ou áreas de Cerrado. Assemelha-se com T. tricholepis, outra espécie do subgênero Diaphoranthema, que reúne outras espécies de pequeno porte. Tillandsia loliacea apresenta folhas rosuladas e caule pouco evidente (vs. folhas dispostas ao longo de todo o caule desenvolvido em T. tricholepis) e raque fortemente geniculada (vs. raque reta a flexuosa) e folhas maiores, de até $3,5 \mathrm{~cm}$ (vs. até $2 \mathrm{~cm}$ ). Coletada com frutos de fevereiro a julho.

3.4. Tillandsia recurvata (L.) L., Sp. pl. ed. 2. 410. 1762. Fig. 2 B-K

Epífita, 6-20 cm compr.; caule 2-5 cm compr., geralmente ramificado na base, raízes presentes. Folhas 2,7-8 cm compr., com ca. de $1 \mathrm{~mm}$ de diâm., dísticas a subdísticas, dispostas ao longo do caule, imbricadas, densamente lepidotas, cinéreas, filiformes, recurvadas a retas. Escapo 4-9 cm compr. Bráctea do escapo 0,7-2 cm compr., 2,3-3 cm larg., 1 ou 2, elíptica ou oval, ápice agudo, com ou sem arista, lepidota, ecarenada. Inflorescência 1-1.9 cm compr., 1-2-flora. Bráctea floral 6-8 $\mathrm{mm}$ compr., 3-3,5 cm larg., semelhante à do escapo. Flores polísticas; sépalas 5-8 $\mathrm{mm}$ compr., ca. $2 \mathrm{~mm}$ larg., oblongo- lanceoladas, ápice agudo; pétalas ca. $1 \mathrm{~cm}$ compr., ca. $0,5 \mathrm{~cm}$ larg., estreitamente oblongas, ápice emarginado, livres, lilásclaro. Estames livres, inclusos. Cápsula 1,8-3 cm compr.

Material examinado: Minas Gerais, Jaboticatubas, Serra do Cipó, M.B. Foster \& R. Foster 632, 12.VII.1940, fr. (SP); Chapéu de Sol, L.B. Smith et al. 7004, 29.IV.1952, fl., fr. (R, US). Santana do Riacho, planalto da Serra do Cipó, H. Strang 1068 \& A. Castellanos 26651, 29.VII.1967, fr. (HB); Condomínio Rio Cipó, A.F. Costa et al. 75, 3.II.1987, fl. (RB); margem do rio Capivara, J.R. Pirani et al. CFSC 10286, 21.VII.1987, fr. (SPF); 10-20 km a NE de Cardeal Mota, M.M. Arbo et al. 4229, 16.V.1990, veg. (SPF); $7 \mathrm{~km}$ a NE de Cardeal Mota, M.M. Arbo et al. 4598, 8.II.1991, veg. (SPF); 7-12 km N de Santana do Riacho, M.M. Arbo et al. 4832, 11.II.1991, fl. (SPF); próximo à sede do IBAMA do vale do rio Cipó, J.R. Pirani et al. CFSC 12040, 25.III,1991, fr. (SPF); morro da Pedreira, M.T.V.A. Campos et al. CFSC 12868, 6.I.1992, fl. (SPF); vale do rio Cipó, J.V. Coffani-Nunes 5, 14.VI.1992, fr. (SPF); Parque Nacional da Serra do Cipó, J.V. Coffani-Nunes 6, 14.VI.1992, fr. (SPF); córrego Duas Pontinhas, J.V. Coffani-Nunes 10, 15.XI.1992, fr. (SPF); Chapéu do Sol, J.V. Coffani-Nunes 25, 19.I.1993, fr. (SPF); Chapéu do Sol, J.V. Coffani-Nunes 38, 1.V.1993, fr. (SPF); morro do Calcário, E.G.A. Martins et al. 90, 15.II.2007, fr. (SPF). Serra do Cipó, J. Badini s.n., 1938, fl. (OUPR 14313).

Espécie com hábito reduzido bem característico, mas apresentando grande similaridade com T. mallemontii Glaz. ex Mez, diferindo dessa, segundo Smith \& Downs (1977), por apresentar pétalas estreitas e inconspícuas e lâmina foliar cilíndrica, densamente cinéreo-lepidota, enquanto T. mallemontii possui pétalas largas e conspícuas; lâmina foliar aplainada ou cilíndrica. Estas características definem os subgêneros Diaphoranthema e Phytarrhiza aos quais as duas espécies pertencem, respectivamente. Mez (1891-1894) também ressalta a forma das pétalas, estreitamente elíptica em $T$. recurvata e suborbicular em $T$. mallemontii, para diferenciá-las. Tillandsia recurvata ocorre do sul dos EUA até Argentina, estando bem representada no território nacional. Enquanto T. mallemontii ocorre da região Nordeste ao Sul do Brasil, porém apresenta apenas um registro em Minas Gerais, na Serra da Mantiqueira (Versieux \& Wendt, 2006). Na Serra do Cipó foi encontrado material em flor entre janeiro e abril.

3.5. Tillandsia streptocarpa Baker, J. Bot. 25: 241. 1887

Fig. $2 \mathrm{~T}$

Rupícola, raramente epífita, $11-38 \mathrm{~cm}$ compr.; caule curto a desenvolvido. Folhas 9,5-13,5 cm compr., 0,8-1,3 cm larg., lineares a lineares-triangulares; bainha 1,6-2 cm compr., 1,4$1,7 \mathrm{~cm}$ larg., largo-oval a suborbicular, membranácea, glabra; lâmina retorcida, reta a recurvada, densamente lepidota, margem involuta. Escapo 13-20 cm compr. Bráctea do escapo 2-3(-4,5) cm compr., maior que o entrenó, dística, lanceolada, ápice agudo, recurvado, densamente lepidota, imbricada. Inflorescência 5-12 cm compr., simples ou composta, ereta. Bráctea floral 1,2-2 cm compr., 0,4-0,6 cm larg., oblongo-elíptica, ápice arredondado, dística. Flores dísticas; 
sépalas 1,2-1,3 cm compr., 0,4-0,5 cm larg., elípticas, ápice acuminado, unidas na base; pétalas ca. $2,5 \mathrm{~cm}$ compr., ca. 1 cm larg., obovais-espatuladas, lilás; estames livres; estilete mais curto que o ovário. Cápsula 2,5-4 cm compr.

Material examinado: Minas Gerais, Conceição do Mato Dentro, Parque Natural Municipal do Ribeirão do Campo, R.C. Mota \& L.M. Versieux 1841, 13.IX.2002, fl. (BHCB). Santana do Riacho, Condomínio Rio Cipó, A. Costa et al. 76, 3.II.1987, fr. (RB); Morro da Pedreira, M.T.V.A. Campos et al. CFSC 13266, 22.07.1993, fr. (SPF); estrada Santana do Riacho - Lapinha, R.C. Forzza et al. 326, 21.X.1997, fr. (SPF); estrada Santana do Riacho - Lapinha, R.C. Forzza et al. 781, 5.III.1998, veg. (SPF); Lapa de Cima, próximo à RPPN Ermo das Gerais, L.M. Versieux \& A.P.G. Faria 147, 28.VIII.2003 fl., fr. (RFA). Lapinha, contrafortes ocidentais da Serra do Cipó, 1906'10"S, 4340’26”W, 1483 m alt., J.R. Pirani et al. 5529, 22.IV.2006, fr. (SPF). Serra do Cipó, J. Vidal s.n., 1949, fr. (R 181356).

Material adicional examinado: São Paulo, Sorocaba (Ipanema), F.C. Hoehne s.n., VII.1933, fl. (SP 29791).

Tillandsia streptocarpa é uma espécie bem caracterizada, com as brácteas do escapo e florais dísticas e com o caule rizomatoso, folhas com margens involutas, frequentemente recurvadas, retorcidas, densamente lepidotas. Apresenta ampla distribuição geográfica, é usualmente rupícola, mas também cresce como epífita. Os exemplares da Serra do Cipó em geral possuem porte ligeiramente menor se comparados aos coletados mais ao norte da Cadeia do Espinhaço. Para alguns autores e em alguns herbários existe uma separação entre T. streptocarpa (plantas epífitas, caule até $10 \mathrm{~cm}$, flores perfumadas, inflorescência raramente simples) e $T$. arhiza Mez (plantas rupícolas, caule até $60 \mathrm{~cm}$, flores inodoras, inflorescência em geral simples). Porém ambas as espécies são de ampla distribuição e essa separação se mostra um tanto artificial, havendo muita sobreposição entre as características diagnósticas para cada uma, o que necessita ser analisado em detalhe. Coletada com flores em agosto e setembro.

3.6. Tillandsia stricta Sol. ex Ker Gawl., Bot. Mag. 37: t. 1529. 1813.

Fig. 2 M-S, 6 E

Epífita, 10-27 cm compr.; caule curto. Folhas 6,9-21 cm compr., 0,6-1,4 cm larg., em roseta, densamente lepidotas; bainha curtíssima, triangular; lâmina estreito-triangular com ápice agudo. Escapo 7,5-12 cm compr. Bráctea do escapo 2-3(-9) cm compr., 0,7-1,7 cm larg., oval ou elíptica, ápice aristado; Inflorescência 4,5-7 cm, simples, subereta ou pêndula. Bráctea escapal 2-9 cm compr., 0,7-17 cm larg., elítptica ou oval, ápice caudado ou aristado. Bráctea floral 1-5,5 cm compr., 0,6-2,4 cm larg., oval a elíptica, ápice caudado, aristado ou mucronado, revestido por escamas na região distal da face abaxial. Flores polísticas; sépalas 0,9$1,5 \mathrm{~cm}$ compr., 0,3-0,4 cm larg., unidas na base, elípticas, carenadas, ápice acuminado; pétalas 0,9-1,4 cm compr., 0,3-0,4 cm larg., espatuladas, rosa ou lilás; estames da série interna epipétalos; estilete maior que $1 \mathrm{~cm}$ de compr.; estigma ereto, papiloso. Cápsula 2-3,8 cm compr.

Material examinado: Minas Gerais, Conceição do Mato Dentro, L. Queiroz 253, 17.III.1991, fl. (BHCB); Parque Natural Municipal do Ribeirão do Campo, R.C. Mota \& L.M. Versieux 1839, 13.IX.2002, fl. (BHCB). Jaboticatubas, Serra do Cipó, M.B. Foster \& R. Foster 633, 12.VII.1940, fr. (SP); Chapéu de Sol, L.B. Smith et al. 7064, 29.IV.1952, fl., fr. (R); fazenda Palácio, G. Hatschbach \& Z. Ahumada 31573, 14.II.1973, fl. (MBM, US); km 114, N.L. Menezes et al. 824, 01.III.1977, fl. (SP); estrada da Usina, M.G.L. Wanderley CFSC 5703, 16.VIII.1979, fr. (SP). Santana do Riacho, km 114, S. Mayo et al. CFSC 7023, 28.II.1981, fl. (SP, SPF, RB); estrada para a Lapinha, C.F. Muniz et al. CFSC 7877, 18.II.1982, fl. (SP, SPF); Parque Nacional da Serra do Cipó, km 135, M.L. Kawasaki et al. CFSC 9142 in part, 5.XI.1983, fr. (SPF); 10-20 km NE de Cardeal Mota, M.M. Arbo et al. 4122, 15.V.1990, fr. (SPF); estrada Santana do Riacho-Lapinha, H.L. Arndt \& A.M. Silva s.n., 9.IX.1990, fr. (BHCB 18705, US); Chapéu de Sol, J.V. CoffaniNunes 24, 19.I.1993, fl. (SPF); Rodovia Belo Horizonte-Conceição do Mato Dentro, km 124, J.V. Coffani-Nunes 31, 13.III.1993, fl. (SPF); $400 \mathrm{~m}$ antes da bifurcação Conceição - Morro do Pilar, M.T.V. Campos et al. CFSC 13545, 21.XI.1993, fl. (SPF); idem, M.T.V. Campos et al. CFSC 13695, 29.III.1993, fr. (SPF); Capão Redondo, P.T. Sano et al. 629, 23.X.1997, fl. (SPF); estrada para Lapinha, R.C. Forzza et al. 770, 5.III.1998, fl., fr. (SPF). Serra do Cipó, J. Badini s.n., 1938, fr (OUPR 14300); J. Vidal s.n., VII.1949, fl. (R); E. Pereira 10462, 23.III.1966, fl. (HB); km 120, H.S. Irwin et al. 20043, 23.III.1966, fl. (MBM, RB); W.R. Anderson et al. 36228, 18.II.1972, fl. (SP); E. Costa 374, 26.II.1984, fr. (RB).

Espécie de ampla distribuição no Brasil, onde ocorre especialmente como epífita em áreas florestais ou, mais raramente, sobre rocha em campo rupestre (Smith \& Downs 1977, Martinelli et al. 2008). Na Serra do Cipó só foi encontrada como epífita. Os espécimes de T. stricta examinados apresentaram grande variação morfológica em relação às dimensões das brácteas florais. $\mathrm{Na}$ região proximal da inflorescência, a bráctea floral apresenta ápice com arista, variando em direção à região distal, onde tornase mucronada. O tamanho da bráctea floral também varia no mesmo sentido, podendo ser três vezes menor na porção distal em relação à região proximal na mesma inflorescência. Fato semelhante pode ser observado nas brácteas do escapo. Em todos os espécimes analisados observou-se a ocorrência de escamas no ápice das brácteas do escapo e florais, aspecto este bastante peculiar, servindo como caráter diagnóstico. O material examinado sugere que o pico da florada ocorra no verão, embora haja material com flor em praticamente todos os meses.

3.7. Tillandsia tenuifolia L., Sp. pl. 286. 1753.

Fig. 2 U-AB

Epífita ou rupícola, $20-50 \mathrm{~cm}$ compr.; caule bem desenvolvido, ramificado ou não. Folhas 6-15 compr., 0,4-1 $\mathrm{cm}$ larg., estreitamente triangulares, densamente lepidotas. 
Escapo 5-8 cm compr. Bráctea do escapo 1,7-4,6 cm compr., 0,5-1,2 cm larg., elíptica a levemente obovada, caudada. Inflorescência 3,5-4,5 cm compr., simples, reta ou recurvada. Bráctea floral 1,1-4,6 cm compr., 0,5-1,2 cm larg., elíptica a oval, ápice apiculado ou aristado. Flores polísticas; sépalas 1,1-1,5 cm compr., 2-3 mm larg., oblongo-elípticas, ápice agudo; pétalas 1,7-2,2 cm compr., 3-4 mm larg., elípticas, alvas, ápice obtuso; estames da série interna epipétalos; estilete longo; estigma ereto, exserto, retorcido, papiloso.

Material examinado: Minas Gerais, Cardeal Mota, Serra do Cipó, W.R. Anderson et al. 36279, 19.I.1972, fr. (HB, SP). Conceição do Mato Dentro, Parque Natural Municipal do Ribeirão do Campo, R.C. Mota \& P.L. Viana 1845, 12.II.2003, fl. (BHCB). Conceição do Serro, Serra do Cipó, W. Schwacke \& P.L. Oliveira 12552, IX.1896, fl. (RB); Santana do Riacho, Serra do Cipó, às margens do rio Cipozinho, G. Martinelli 4277, 26.IV.1978, fl., fr. (HB, RB); Serra do Cipó, G. Martinelli 4379, 27.IV.1978, fr. (RB); Morro do Calcário, M.G. Arrais et al. CFCR 5896, 13.XI.1984, fl. (SPF, RB); Rodovia Belo Horizonte-Conceição do Mato Dentro, km 124, L.C. Giordano \& Toscano 680, 30.IV.1989, fl. (RB); km 125, J.R. Pirani et al. CFSC 12055, 26.III.1991, fl. (SPF); km 124, J.V. Coffani-Nunes 29, 13.III.1993, fl. (SPF); km 124, J.V. CoffaniNunes 30, 13.III.1993, fl. (SPF); Serra do Cipó, L. Queiroz \& A. G. Freire s.n., 1.V.1991, fl. (BHCB 20767); Parque Nacional Serra do Cipó, J.V. Coffani-Nunes 28, 16.II.1992, fl. (SPF); idem, J.V. Coffani-Nunes 40, 2.V.1993, fr. (SPF); capão de mata, 19¹5'36.7''S 4332'32.9'W, 1378 m.s.m., L.M. Versieux \& P.M. Elbl 482, 26.IV.2009, fr. (SP). Serra do Cipó, J. Baldini \& H. Mello-Barreto s.n., 1938, veg. (OUPR 14320); Serra do Cipó, J. Vidal s.n. VII.1949, bt. (R 107665).

Na Serra do Cipó a espécie é encontrada como epífita ou rupícola. Apresenta ampla distribuição geográfica e, eventualmente, é confundida com T. stricta. Entretanto, difere pelo caule mais desenvolvido e ramificado, pelas brácteas florais mais estreitas e sem escamas na porção distal. Tillandsia tenuifolia apresenta uma grande plasticidade morfológica, sendo reconhecidas cinco variedades. Em função da sobreposição dos caracteres diagnósticos entre tais variedades, esse nível hierárquico não foi adotado no presente trabalho.

3.8. Tillandsia tricholepis Baker, J. Bot. 16: 237. 1878.

Fig. 2 AC

Epífita, 3,5-11 cm compr.; caule conspícuo, delgado. Folhas 1-2 cm compr., 2-3 mm larg., dispostas ao longo do caule, alterno-espiraladas, eretas a suberetas, retas a encurvadas, densamente lepidotas; bainha largo-oval, membranácea; lâmina estreito-triangular, involuta, densamente ferrugínea ou cinéreo-furfurácea. Escapo 2,5-4,5 cm compr., delgado. Brácteas do escapo 7-10 mm compr., 2-3 mm larg., lanceoladas, ápice agudo, imbricadas a quase remotas, lepidotas. Inflorescência 1-2 cm compr., simples, 1-5-flora; raque quase reta a flexuosa, glabra. Brácteas florais 6-9 $\mathrm{mm}$ compr., 3-4 mm larg., ovais, ápice agudo, verde-acinzentadas, lepidotas. Flores dísticas; sépalas 5-6 mm compr., ca. $2 \mathrm{~mm}$ larg., livres, lanceoladas, ápice agudo, glabras; pétalas 7-8 mm compr., liguladas, ápice agudo, amarelas; estames inclusos; estilete mais curto que o ovário. Cápsula 1,5-2,5 cm compr.

Material examinado: Minas Gerais, Cardeal Mota, $10 \mathrm{~km} \mathrm{~S} \mathrm{da} \mathrm{Serra}$ do Cipó, W.R. Anderson et al. 36277, 19.II.1972, fl. (US). Santana do Riacho, Morro da Pedreira, J.R. Pirani et al. CFSC 13268, 22.VII.1993, fr. (SPF).

Material adicional examinado: São Paulo, Itupeva, M.G.L. Wanderley et al. 2141, IV.1995, fr. (SP).

Espécie de ampla distribuição com apenas dois registros para a Serra do Cipó. Pode ser reconhecida pelo porte delicado e padrão de ramificação do caule. O material coletado na Serra do Cipó apresenta menor tamanho, se comparado às coleções de áreas de floresta atlântica.

3.9. Tillandsia usneoides (L.) L., Sp. pl. ed. 2. 411. 1762. Fig. 3 A-H

Epífita pendente; caule de tamanho variável, muitas vezes passando de $1 \mathrm{~m}$ compr., ramificado, com menos de $1 \mathrm{~mm}$ diâm., entrenós entre 1,9-10 cm compr., filiforme, densamente lepidoto, cinéreo. Folhas 2,3-7 cm compr., menos de $1 \mathrm{~mm}$ diâm., dísticas, filiformes, densamente lepidotas, cinéreas. Escapo e raízes ausentes. Bráctea floral muito reduzida, envolvendo a base da flor, filiforme, marcescente, densamente lepidota, exceto nas porções laterais e basal. Flor isolada; sépalas ca. $7 \mathrm{~mm}$ compr., $2 \mathrm{~mm}$ larg., elípticas, ápice agudo, unidas próximo à base; pétalas $10-11 \mathrm{~mm}$ compr., ca. $1 \mathrm{~mm}$ larg., amareladas a esverdeadas, liguladas, ápice agudo; estames livres, inclusos, maiores que o estilete; estilete ca. 1 mm compr; estigma, incluso, ereto, papiloso. Cápsula 1,5-2,6 cm compr.

Material examinado: Minas Gerais, Conceição do Mato Dentro, Parque Natural Municipal do Ribeirão do Campo, R.C. Mota \& P.L. Viana 1836, 1.VIII.2002, veg. (BHCB). Congonhas do Norte, setor $\mathrm{N}$ da Serra do Cipó, J.R. Pirani et al. 4188, 3.III.1998, veg. (SP, SPF). Santana do Riacho, Rodovia Belo Horizonte-Conceição do Mato Dentro, km 120, H.S. Irwin et al. 20304a, 16.II.1968, fr. (SEL); km 116, A. Furlan et al. CFSC 7231, 19.IV.1981, fr. (RB, SP, SPF); alto Congonhas, M.M. Arbo et al. 4766, 9.II.1991, veg. (SPF); córrego das Três Pontinhas, J.V. Coffani-Nunes 9, 15.IX.1992, veg. (SPF).

Com um hábito muito característico, T. usneoides é reconhecida mesmo quando estéril. O caule pendente e suas folhas cinéreo-lepidotas, filiformes, formando "cortinas", são únicos na família. Também conhecida como "barba de velho" ou "crina vegetal", T. usneoides, geralmente é encontrada em estado vegetativo. As flores são solitárias, pequenas e se confundem no emaranhado do caule e folhas. A ampla distribuição de T. usneoides na região Neotropical coincide, praticamente, com a área total de ocorrência da família. Dentro do Parque a espécie ocorre em matas de galeria. 


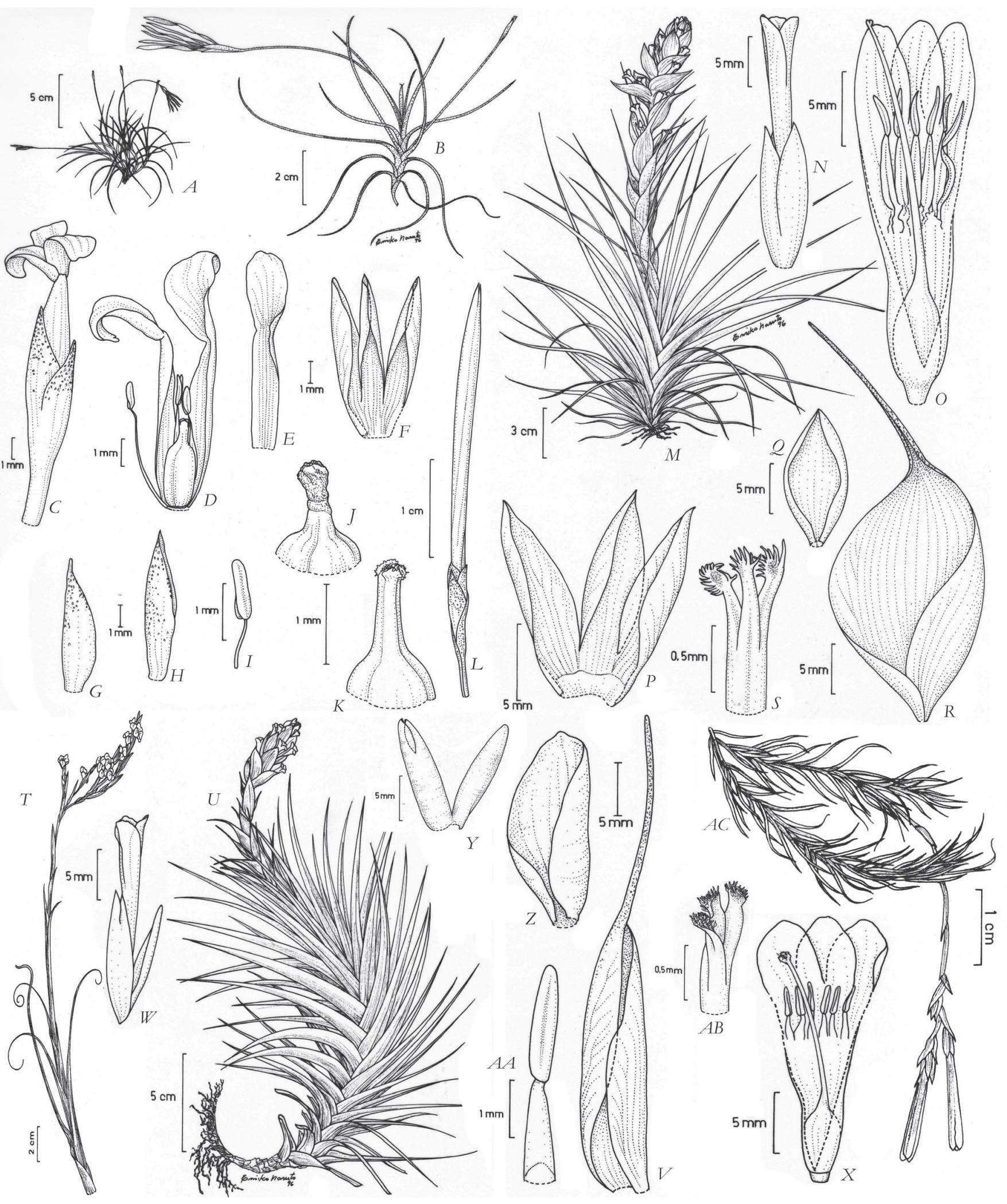

Fig. 2. A. Tillandsia loliacea. Hábito, B-L. T. recurvata. B. Hábito, C-D. Flor, E. Pétala, F. Sépalas, G. Bráctea floral, H. Bráctea primária, I. Estame, J. Estigma, L. Cápsula. M-S. T. stricta. M. Hábito, N-O. Flor, P. Sépalas, Q-R. Brácteas florais, S. Estigma. T. T. streptocarpa, Hábito. U-AB. T. tenuifolia. U. Hábito, V. Bráctea floral, W-X. Flor, Y. Sépalas, Z. Pétalas, AA. Estame, AB. Estigma. AC. T. tricholepis, Hábito. [A. Tamashiro 454, B-L. Coffani-Nunes 25, M-S. Coffani-Nunes 24, T. Hoehne s.n. (SP 29791), U-AB. Coffani-Nunes 28, AC. Wanderley 2141]. 


\section{Vriesea Lindl.}

Ervas perenes, epífitas, rupícolas, saxícolas ou terrestres. Folhas em rosetas, formando tanque; lâminas predominantemente liguladas ou lanceoladas e inconspicuamente lepidotas. Escapo geralmente conspícuo. Inflorescência simples ou composta. Bráctea floral geralmente conspícua. Flores dísticas ou secundas; sépalas livres, simétricas ou subsimétricas; pétalas livres ou curtamente conatas, 2 apêndices petalíneos basais na face interna, firmes, eretas ou encurvadas. Estames inclusos ou exsertos. Ovário súpero; pluriovulado, óvulos caudados. Fruto cápsula septicida, geralmente cilíndrico ou ovóide; sementes fusiformes com apêndice plumoso na base.

Chave para as espécies

1. Pétalas amarelas com máculas púrpuras nos bordos

4.1. V. atropurpurea

1'. Pétalas amarelas sem máculas púrpuras.

2. Brácteas florais cor de rosa.

3. Lâminas foliares lineares, com máculas arroxeadas formando pequenas faixas transversais em toda a extensão, ápice obtuso.

4.5. V. guttata

3'. Lâminas foliares linear-triangulares, com máculas arroxeadas apenas acima da bainha, ápice agudo

4.9. V. piscatrix

2'. Brácteas florais verdes, amarelas, vermelhas ou castanhas.

4. Inflorescência simples (sem ramos laterais).

5. Flores secundas na antese.

6. Brácteas florais ovais, menores que as sépalas

4.8. V. oligantha

6 '. Brácteas florais estreito-triangulares, maiores que as sépalas

4.7. V. longicaulis

5 '. Flores dísticas na antese.

7. Bráctea floral 1,5-2,5 cm compr., com máculas vinosas, planta rupícola

4.3. V. cipoensis

7'. Bráctea floral 3,2-5 cm compr., sem máculas vinosas, planta epífita ou terrícola

4.2. V. bituminosa

4'. Inflorescência composta (ramificada).

8. Planta rupícola; flores secundas na antese (porém botões florais dísticos).

9. Planta florida com até $0,5 \mathrm{~m}$ alt.; folha ereta, menor que $40 \mathrm{~cm}$ compr.; sépalas 2,4-3,2 cm compr. 4.12. V. stricta

9'. Planta florida com até. $2,5 \mathrm{~m}$ alt.; folha subereta, maior que $50 \mathrm{~cm}$ compr.; sépalas 3,3-4 cm compr.

4.6. V. hoehneana

8'. Planta epífita; flores dísticas na antese.

10. Bráctea primária menor que os pedúnculos laterais, bráctea floral menor ou igual a $2,3 \mathrm{~cm}$ compr.

4.11. V. segadas-viannae

10 '. Bráctea primária maior que os pedúnculos laterais, bráctea floral maior ou igual a $2,5 \mathrm{~cm}$ compr.

11. Bráctea floral se igualando às sépalas, ramos da inflorescência com 8-12 flores 4.10. V. schwackeana

11'. Bráctea floral distintamente mais curta que as sépalas, ramos da inflorescência com 4-7 flores

4.4. V. friburgensis

4.1. Vriesea atropurpurea Silveira, Fl. Montium 2 (add.): 3, t. 131.1931 .

Fig. 3 I-O, 6 F-H

Terrícola, ca. 1,7 m compr. Folhas 19-44 cm compr., 3,8$5,4 \mathrm{~cm}$ larg., lanceoladas, ápice agudo, suberetas a eretas; bainha 6-8,3 cm larg., castanho-arroxeada; lâmina verde, vinosa a púrpura em direção ao ápice. Escapo $0.7-1.3 \mathrm{~cm}$ compr. Brácteas superiores do escapo 2,3-7,5 cm compr., 1,72,8 cm larg., oval-lanceoladas ou lanceoladas, eretas, quase se igualando ao entrenó. Inflorescência $16-40 \mathrm{~cm}$ compr., simples ou com uma ramificação basal, cada ramo com 2-16 flores, glabra, ereta. Bráctea primária igual à do escapo. Bráctea floral 1,1-2,9 cm compr., menor que as sépalas na antese, oval, verde-acastanhada. Flores dísticas; sépalas 2,8-3,8 cm compr., 1,2-1,7 cm larg., levemente obovais, ápice obtuso, verdes, eventualmente com os bordos vinosos, lepidotas na face adaxial; pétalas 4-4,7 cm compr., 1,1-1,7 cm larg., oblongas, acuminadas, amareladas com máculas purpúreas; estames exsertos. Cápsula ca. $4,5 \mathrm{~cm}$ compr.

Material examinado: Minas Gerais, Santana do Riacho, Serra do Cipó, Alto Palácio, km 133-135, E.M.C. Leme et al. 1831, 23.XI.1991, fr. (HB); idem, E.M.C. Leme et al. 1830, IV.1996, fl. em cult. (HB); idem, M.G.L. Wanderley et al. 2492, 11.XII.2005, fr. (SP); idem, L.M. Versieux et al. 296 e 297, 8.X.2006, fl. (SPF, SP); idem, 19¹4'50.1”S, 43031'08.9'W, 1320m, L.M. Versieux et al. 483, 26.IV.2009, fr. (SP); Rodovia Belo Horizonte-Conceição do Mato Dentro, km 135, J.V. Coffani-Nunes 20, 17.X.1992, fr. (SPF); km 135, J.V. Coffani-Nunes 35, 14.III.1993, fr. (SPF); campo de cimeira ao norte da base do IBAMA do Alto do Palácio, J.R. Pirani et al. CFSC 13201, 20.VII.1993, bt., fl. (SPF); Parque Nacional da Serra do Cipó, perto dos afloramentos rochosos das Velózias gigantes, A.R. Marques s.n., 27.VIII.1998, fl. (BHCB 42943). 


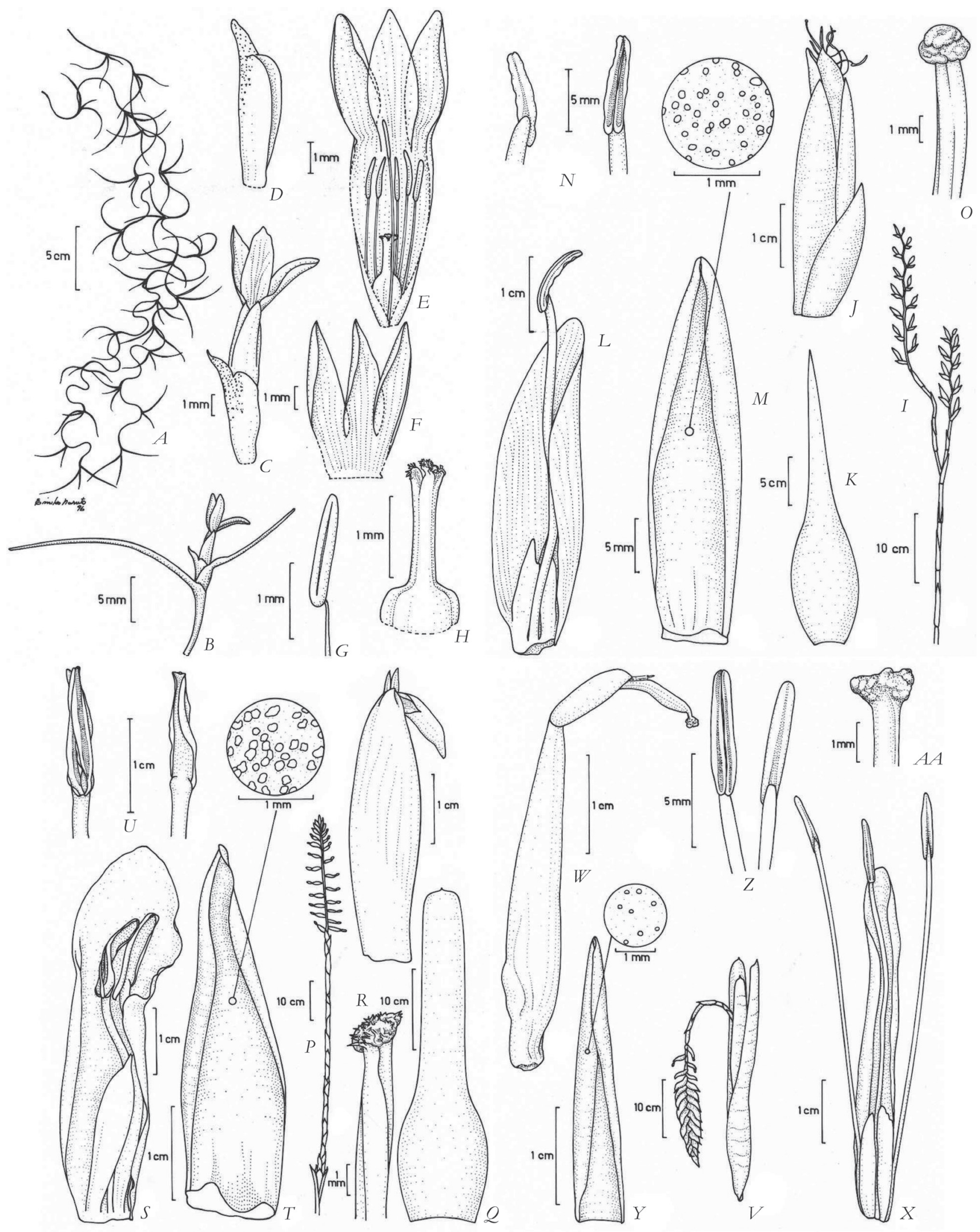

Fig. 3. A-H. Tillandsia usneoides. A. Hábito, B-C. Flor, D. Bráctea floral, E. Flor aberta. F. Sépalas, G. Estame, H. Estigma. I-O. Vriesea atropurpurea. I. Inflorescência, J. Flor, K. Folha, L. Pétala, M. Sépala, N. Antera (dorsal e ventral), O. Estigma. P-U. V. bituminosa. P. Inflorescência, Q. Folha. R. Estigma, S. Pétala, T. Sépala, U. Antera (ventral e dorsal). V-AA. V. guttata. V. Hábito. W. Flor passada. X. Pétala. Y. Sépala, Z. Antera (ventral e dorsal), AA. Estigma. [A-H. Coffani-Nunes 9, I-O. Coffani-Nunes 20, P-U. Coffani-Nunes 23, V-AA. Coffani-Nunes 26]. 
Espécie bem delimitada, distinta das demais Vriesea da Serra do Cipó em virtude de possuir pétalas amarelas maculadas de púrpura (Figura $6 \mathrm{G}$ ). A espécie é próxima de $V$. longistaminea Leme \& C.C. Paula, também de Minas Gerais, mas com ocorrência restrita à região do Quadrilátero Ferrífero e com pétalas totalmente amarelas. A adoção de diferentes circunscrições por diferentes autores no passado e em virtude da ilustração da Flora Neotropica que retrata $V$. atropurpurea (Smith \& Downs 1977: t. 403) corresponder, de fato, a outra espécie, V. minarum L.B.Sm. (que não ocorre na Serra do Cipó), acabaram gerando equívocos na identificação em herbários. Entretanto, V. atropurpurea é uma espécie rara, restrita ao Parque Nacional Serra do Cipó, no qual só possui ocorrências para região do Alto do Palácio, onde cresce em campo arenoso entre gramíneas. Observada com botões no mês de maio e flores entre os meses de julho e outubro. Frutos maduros coletados em abril.

4.2. Vriesea bituminosa Wawra, Osterr. Bot. Z. 12: 347. 1862.

Fig. 3 P-U

Epífita ou terrícola, 0,9-1,2 m compr. Folhas $37-51 \mathrm{~cm}$ compr., 5,5-7 cm larg., liguladas, bainha 8,5-9,6 cm larg., elíptica, castanho-escura quase negra abaxialmente; lâmina verde a verde-acastanhado, eventualmente com linhas oblíquas verde-escuras, ápice arredondado, com mácula negra, mucronada, mucro 5-10 mm compr. Escapo 40-80 cm compr. Brácteas superiores do escapo 4,2-6 cm compr., 3,5-3,8 cm larg., maiores que os entrenós, oval-lanceoladas, imbricadas, eretas. Inflorescência 30-40 cm compr., simples, coberta por abundante mucilagem, 28-34-flora, ereta. Brácteas florais 3,2$5 \mathrm{~cm}$ compr., 3-3,9 cm larg., ovais, decorrentes com a raque, castanhas. Flores dísticas; sépalas 4-4,5 cm compr., 1,4-1,6 $\mathrm{cm}$ larg., obovais, castanhas, lepidotas na face abaxial; pétalas 5,5-6 cm compr., 1,5-1,7 cm larg., amarelas; estames inclusos. Cápsula ca. $5 \mathrm{~cm}$ compr.

Material examinado: Minas Gerais, Conceição do Mato Dentro, Parque Natural Municipal do Ribeirão do Campo, R.C. Mota 1869, 28.XII.2002, fl. (BHCB). Santana do Riacho, Parque Nacional da Serra do Cipó, Rodovia Belo Horizonte-Conceição do Mato Dentro, km 126, J.V. Coffani-Nunes 3, 14.VI.1992, fr. (SPF); Serra do Cipó, J.V. CoffaniNunes 23, 19.I.1993, fl. (SPF).

Espécie de ampla distribuição, ocorrendo da Venezuela ao leste do Brasil. Forma um complexo que esta sendo revisado, envolvendo outros táxons da seção Xiphion como V. atra Mez, V. jonghei (K. Koch.) E. Morren, V. minor (L.B.Sm.) Leme, $V$ platynema Gaudich., entre outros. Na Serra do Cipó cresce como epífita ou terrestre em capões de mata, próximo a cursos d'água. Foi observada em flor nos meses de dezembro e janeiro.

4.3. Vriesea cipoensis O. B. C. Ribeiro, C. C. Paula \& E. E. Guarçoni, J. Bromeliad Soc. 59(1): 8. 2009.

Fig. 5 E-G, 6 I
Rupícola, ca. 1,1 m compr. Folhas 50-60 cm compr., 5-6 cm larg., lineares; bainha 14-16 cm compr., 10-12 cm larg., castanho-escura; lâmina verde com máculas roxas logo acima da bainha, ápice obtuso, mucronado, mucro 5-10 mm compr. Escapo 60-80 cm compr. Brácteas superiores do escapo 2,5$5 \mathrm{~cm}$ compr., ca. 2,2 cm larg., aproximadamente do mesmo tamanho ou pouco maiores que os entrenós, ovais, eretas, com máculas roxas. Inflorescência $20-30 \mathrm{~cm}$ compr., ca. 10 cm larg., 20-40-flora, simples, ereta. Brácteas florais 1,52,5 cm compr., 1,7 cm larg., menores que as sépalas, largoovais, ápice obtuso, dísticas, patentes a reflexas na antese, decorrentes com a raque, verdes, coriáceas, ecarenadas. Flores ca. $5,5 \mathrm{~cm}$ compr., dísticas; sépalas ca. $2,5 \mathrm{~cm}$ compr., ca. 1,5 cm larg., elípticas a levemente obovais, verde-amareladas; pétalas 4,2-4,5 cm compr., 1,6-1,8 cm larg. na porção distal, obovais, amarelas; estames ca. 3,6 cm compr., inclusos.

Material examinado: Minas Gerais, Conceição do Mato Dentro, Parque Natural Municipal do Ribeirão do Campo, R.C. Mota \& P.L. Viana 1868, 12.II.2003, fl. (BHCB); Parque Natural Municipal do Ribeirão do Campo, R.C. Mota 2170, 19.III.2003, fl. (BHCB, RFA). Jaboticatubas, Serra do Cipó, R. Reitz 7866, 21.V.1975, fl. (HBR, SP).

Táxon reconhecido pela inflorescência simples com flores dísticas e brácteas florais com aurículas decorrentes com a raque e fortemente recobertas por um néctar viscoso. É próxima de $V$. bituminosa que, no entanto, apresenta brácteas florais maiores, cresce como epífita ou terrícola em áreas sombreadas (vs. rupícola, heliófila) e não possui as máculas vinosas que podem ser vistas aqui nas brácteas escapais, florais e nas folhas (Fig. 6 I). O padrão de máculas arroxeadas e os estames mais curtos são algumas das diferenças entre as populações da Serra do Cipó e as populações típicas de $V$. minor do planalto de Diamantina (MG). Este táxon integra um complexo de espécies que está sendo revisado atualmente e comparações com um maior número de coleções da Cadeia do Espinhaço são necessárias para se entender se as diferenças observadas aqui se tratam de variação clinal entre tais populações ou de táxons realmente distintos. Também é importante averiguar qual é o relacionamento entre $V$. cipoensis com $V$. minor e $V$. jonghei, considerando a circunscrição original da última espécie, como já discutido por Versieux \& Wendt (2006). Ocorre exclusivamente em áreas abertas e ensolaradas, onde as rosetas assumem coloração verde-amarelada, e a inflorescência ao se desenvolver em frutos vai sofrendo uma leve torção. Observada com flores entre fevereiro e maio.

4.4. Vriesea friburgensis Mez in Mart., Eichler \& Urb., Fl. bras. 3(3): 537. 1894.

Fig. 5 A-B

Epífita, 0,5-1 m compr. Folhas 30-40 cm compr., 3-4,5 cm larg.; bainha 10-14 cm compr., 7-8 cm larg., castanho-arroxeada a bege; lâmina verde a vinácea, ligulada, ápice obtuso, mucronado, mucro ca. $5 \mathrm{~mm}$ compr. Escapo $25-40 \mathrm{~cm}$ compr. Brácteas superiores do escapo 6-8 cm compr., ca. 3,5 cm larg., 
ovais, eretas, maiores que os entrenós. Inflorescência ca. $25 \mathrm{~cm}$ compr., composta, laxa, ereta, ramos suberetos, glabra, 6-10 ramos, 4-7-floridos. Brácteas primárias 3-7 cm compr., 2-3 cm larg., maiores que os pedúnculos laterais, ovais, ápice agudo a obtuso. Brácteas florais 2,5-4 cm compr., 2-2,5 cm larg. menores que as sépalas, ovais, levemente carenadas no ápice, amarelas, dísticas. Flores dísticas; sépalas 3-3,5 cm compr., 0,8-0,9 cm larg., oblongo-elípticas, amarelo-esverdeadas, membranáceas; pétalas ca. 4,2 cm compr., ca. 0,5 cm larg., lineares, amarelas. Estames exsertos. Cápsula ca. $4 \mathrm{~cm}$ compr.

Material examinado: Minas Gerais, Conceição do Mato Dentro, Parque Natural Municipal do Ribeirão do Campo, R.C. Mota \& P.L. Viana 1866, 8.XI.2002, fl. (BHCB, RFA).

Material adicional examinado: Minas Gerais, Caeté, Serra da Piedade, A.R. Marques s.n., 19.VIII.2000, fr. (BHCB 53919). Santa Bárbara, Parque Natural do Caraça, M.B. Horta et al. s.n., 10.XII.1986, fl. (BHCB 8953); Serra do Caraça, M.F. Vasconcelos s.n., 22.XII.1997, fl. (BHCB 40230); Serra do Caraça, M.F. Vasconcelos s.n., 13.XII.1998, fl. (BHCB 45827). São Gonçalo do Rio Preto, Parque Estadual do Rio Preto, P.L. Viana et al. 1257, 3.X.2003, fl. (BHCB); Parque Estadual do Rio Preto, M.G.L. Wanderley 2611, 24.V.2007, fr. (BHCB, SP).

Espécie com apenas um registro na Serra do Cipó, entretanto com ampla distribuição no Brasil (Martinelli et al. 2008) e muito frequente em outras áreas da Cadeia do Espinhaço, tanto ao norte quanto ao sul da Serra do Cipó. Com base no material adicional examinado pode-se observar que foi coletada com flores de outubro a dezembro e com frutos entre maio e agosto.

4.5. Vriesea guttata Linden \& André, Ill. Hort. 22: 43. 1875.

Fig. 3 V-AA

Epífita, 50-70 cm compr. Folhas 30-51 cm compr., 3-4 cm larg., liguladas; bainha 5-7,2 cm larg., castanho-arroxeada; lâmina verde, com máculas purpúreas formando faixas transversais em toda a lâmina, ápice arredondado, mucronado. Escapo ca. $20 \mathrm{~cm}$ compr. Brácteas superiores do escapo 3,8-5 cm compr., 2-3,8 cm larg., ovais, eretas, imbricadas, maiores que os entrenós. Inflorescência ca. $15 \mathrm{~cm}$ compr., simples, pendente, 22-38-flora. Bráctea floral 2,5-4,2 cm compr., 2,8$3,7 \mathrm{~cm}$ larg., quase se igualando às sépalas na antese, rósea, oval, pulverulenta. Flores dísticas; sépalas 2,5-3,2 cm compr., 0,9-1,3 cm larg., amareladas, ovais; pétalas 3,5-4,5 cm compr., 0,5-0,7 cm larg., liguladas, amarelas; estames exsertos.

Material examinado: Minas Gerais, Jaboticatubas, Serra do Cipó, J. Badini \& H. Mello-Barreto s.n., II.1938, fr (OUPR 13876). Santana do Riacho, km 132, fundos do Palácio, A.P. Duarte 2233, 8.XII.1945, fl., fr. (RB, US); Parque Nacional da Serra do Cipó, Serra da Bandeirinha, L.R. Parra et al. CFSC 12990, 9.IX.1992, fl. (SPF); Parque Nacional da Serra do Cipó, J.V. Coffani-Nunes 26, 19.I.1993, fl. (SPF); capão de mata em campo rupestre, $19^{\circ} 09^{\prime} 30.5$ 'S, 43 '31'0.78'W, 1300 m.s.m., M.G.L. Wanderley et al. 2473, 10.XII.2005, fl. (SP).
Espécie muito semelhante a $V$. pardalina Mez, da qual se distingue pela disposição, forma e tamanho das brácteas florais. Em V. pardalina as brácteas florais são imbricadas, não expondo a raque, enquanto em $V$. guttata, na porção proximal, as brácteas florais e as respectivas flores são espaçadas entre si, expondo a raque. Espécie de ampla distribuição no Brasil, ocorrendo da região Sudeste ao Sul (Smith \& Downs 1977). Foi observada como epífita em Vellozia no campo rupestre e, mais frequentemente, no interior de pequenos capões de mata. Coletada em flor nos meses de setembro, dezembro e janeiro.

4.6. Vriesea hoehneana L.B.Sm., Proc. Amer. Acad. Arts 68: 150.1933.

Fig. 4 A-C, $6 \mathrm{~J}$

Rupícola, 1,6-2,5 m compr. Folhas 50,5-86,5 cm compr., 7-10,6 cm larg., liguladas, suberetas; bainha 10-18,5 cm larg., castanho-escura; lâmina verde a acastanhado-rosada para o ápice, ápice agudo a subobtuso, mucronado. Escapo ca. 1,3 m. compr. Brácteas superiores do escapo 3,5-8 cm compr., 3,5-8 cm larg., menores que os entrenós, largo-ovais, eretas. Inflorescência 30$60 \mathrm{~cm}$ compr., composta, laxa, ereta, ramos $28-57,5 \mathrm{~cm}$ compr., 2-4, 13-25-floridos. Bráctea primária semelhante às escapais. Bráctea floral 2,3-4 cm compr., 2,5-4 cm larg., orbicular, acuminada, menor que as sépalas na antese, castanho-lustrosa in sicco. Flores secundas; sépalas 3,3-4 cm compr., 1,8-2,1 cm larg. elípticas; pétalas 5,9-6,3 cm compr., 1,3-1,7 cm larg., levemente obovadas, amarelas, ápice ligeiramente recurvado na antese; estames ca. 5,6 cm compr., inclusos. Cápsula ca. 3,5 cm compr.

Material examinado: Minas Gerais, Conceição do Mato Dentro, Serra do Cipó, R.C. Forzza 135, 27.X.1995, fl. (SPF); Parque Natural Municipal do Ribeirão do Campo, R.C. Mota 1867, 28.XII.2002, fl. (BHCB, RFA). Santana do Riacho, Serra do Cipó, km 137, A.P. Duarte 11928, 21.X.1969, bt. (BHCB, HUEFS); próximo ao entroncamento Morro do Pilar - Conceição do Mato Dentro, G. Martinelli 4296, 27.IV.1978, fr. (RB); a $3 \mathrm{~km}$ da portaria do Alto Palácio do IBAMA, região das canelas-de-ema gigantes, M. Pereira \& M. Lucca et al. 1052, 27.VIII.1992, fr. (BHCB); km 128, J.V. Coffani-Nunes 18, 17.X.1992, fr. (SPF); km 128, J.V. Coffani-Nunes 33, 14.III.1993, fr. (SPF); a 3 km da portaria do Alto Palácio do IBAMA, M. Lucca et al. 31, 5.I.1993, fl. (BHCB); próximo às Vellozia gigantea, M.G.L. Wanderley et al. 2642, 20.XI.2008, fl. (SP); 19¹4'50.6”'S, 43030'37.6”'W, 1259m, L.M. Versieux et al. 484, 26.IV.2009, fr. (SP).

Espécie bem delimitada pelo seu porte robusto, sendo que quando florida atinge até $2,5 \mathrm{~m}$ de altura. Apresenta, ainda, outras características bem marcantes como as brácteas do escapo de coloração verde-acastanhadas, brácteas florais castanho-lustrosas in sicco, bainhas marrom-escuro, quase negras e flores secundas. Na Serra do Cipó, $V$. hoehneana vinha sendo confundida com Vriesea crassa Mez, entretanto difere dessa última por possuir inflorescência com ramos mais longos e mais espaçados e também pela coloração das brácteas. Ambas as espécies pertencem à seç̧ão Xiphion, com flores e brácteas em geral de coloração pouco vistosa, corola levemente campanulada, que são indícios 
de polinização por morcegos. Trata-se de uma espécie que ocorre em vegetação campestre, nas áreas elevadas do Sudeste do Brasil. No Parque Nacional Serra do Cipó pode ser encontrada na região do Alto do Palácio e também no alto da cachoeira do Tabuleiro. Frequentemente adquire coloração rosada-vinosa ou até mesmo verde-acastanhada no ápice das folhas e o escapo também pode variar de verde a verde-avermelhado. Os indivíduos da Serra do Cipó vem sendo estudados quanto à sua anatomia, comparandoos com os dados de exemplares coletados na localidade-típica (Alto da Serra, Santo André, SP), uma vez que as brácteas florais e apêndices petalíneos são diferentes entre essas populações. Indivíduos floridos foram observados entre os meses de outubro e janeiro.

4.7. Vriesea longicaulis (Baker) Mez in Mart., Eichler \& Urb., Fl. bras. 3(3): 542. 1894.

Fig. 5 C-D

Epífita ou terrestre, 0,8-1 m compr. Folhas 34-49 cm compr., 2,2-3,2 cm larg., lineares; bainha 6-7,5 cm larg., castanho-escura; lâmina verde-concolor, lustrosa na face adaxial, ápice agudo a subobtuso, mucronado. Escapo ca. 50-85 cm compr. Brácteas superiores do escapo 5-8 cm compr., ca. $2 \mathrm{~cm}$ larg., maiores que os entrenós, oblongo-lanceoladas, eretas, imbricadas. Inflorescência 17-38 cm compr., simples, glabra, 13-30-flora, ereta a levemente recurvada. Brácteas florais (3-)3,5-4,5(-6) cm compr., 2-2,7 $\mathrm{cm}$ larg., maiores que as sépalas, estreito-triangulares, ápice agudo proeminente, secundas na antese, castanho-escuras, esparsamente lepidotas. Flores dísticas passando a secundas na antese; sépalas ca. 2,6 cm compr., ca. 1,2 cm larg., elípticas, amarelo-esverdeadas; pétalas 3,5-4 cm compr., ca. 1,2 cm larg., obovadas, amarelas; estames inclusos. Cápsula ca. $5 \mathrm{~cm}$ compr.

Material examinado: Minas Gerais, Conceição, Serra do Cipó, Vaccaria, 1400 m.s.m., M.B. Foster \& R. Foster 604, 12.VII.1940, fl. (SP). Santana do Riacho, Serra do Cipó, capão de mata em campo rupestre, $19^{\circ} 09^{\prime} 30.5^{\prime}$ 'S, $43^{\circ}$ '31'0.78”'W, 1300 m.s.m., M.G.L. Wanderley et al. 2473, 10.XII.2005, fr. (SP).

Material adicional examinado: Minas Gerais, Rio Preto, Ninho da Égua, M.G.L. Wanderley et al. 2556, 3.VI.2006, fl. (SP).

Espécie bem caracterizada pelas flores secundas na antese e forma das brácteas florais longas, agudas, castanhas, lisas, quebradiças e com ápice paleáceo (Figura 5D). Apresenta distribuição nas regiões Sudeste e Sul do Brasil, sendo característica da mata atlântica (Martinelli et al. 2008). Na Serra do Cipó ocorre em capões, na base dos troncos das árvores em áreas sombreadas ou, mais raramente em áreas de campo. Coletada com flores em julho e com frutos em janeiro.

4.8. Vriesea oligantha (Baker) Mez in Mart., Eichler \& Urb., Fl. bras. 3(3): 544. 1894.

Fig. 4 D-I

Epífita ou rupícola, 50-60 cm compr. Folhas 17-39 cm compr., $(0,8-) 1,5-2,7 \mathrm{~cm}$ larg., linear-triangulares, eretas, revolutas in sicco; bainha 4-8 cm larg., castanho-arroxeada, lâmina verde densamente cinéreo-lepidota, ápice agudo. Escapo 32-67 $\mathrm{cm}$ compr. Brácteas superiores do escapo 1,9-5 cm compr., 0,6-1,6 cm larg., aproximadamente do mesmo tamanho dos entrenós, raramente mais curtas, lanceoladas, eretas, cinéreolepidotas. Inflorescência ca. $15 \mathrm{~cm}$ compr., simples, laxa, ereta a levemente recurvada, glabra, 4-12-flora. Brácteas florais 1,52,8 cm compr., 1-1,8 cm larg., menores que as sépalas, ovais, levemente acuminadas, secundas, verdes, cinéreo-lepidotas abaxialmente. Flores secundas; sépalas 2,8-3,2 cm compr., 0,91,4 cm larg., amarelo-esverdeadas, lanceoladas; pétalas 3,5$4 \mathrm{~cm}$ compr., 0,7-1 cm larg., lanceoladas, amarelas; estames inclusos. Cápsula ca. $5,5 \mathrm{~cm}$ compr.

Material examinado: Minas Gerais, Conceição do Mato Dentro, rio Santo Antônio, G. Martinelli 2605, 16.VII.1977, fr. (RB); Parque Natural Municipal do Ribeirão do Campo, R.C. Mota et al. 1843, 8.XI.2002, fl. (BHCB); Serra da Ferrugem, Fazenda do Toninho, P.L. Viana 2275, 19.VIII.2006, fr. (BHCB). Jaboticatubas, Serra do Cipó, $5 \mathrm{~km}$ ao norte do Chapéu de Sol, L.B. Smith et al. 6696, 29.IV.1952, fr. (R). Santana do Riacho, Serra do Cipó, estrada da Usina, km 2, A.B. Joly et al CFSC 1194, 5.III.1972, fl. (SP, UEC); Rodovia Lagoa Santa - Conceição do Mato Dentro, km 114, J. Semir et al. CFSC 4796, 10-15.XII.1973, fl. (SP, UEC); $7 \mathrm{~km}$ ao N do Chapéu do Sol, G. Martinelli 872, 4.VI.1976, fl., fr. (RB); km 115, N.L. Menezes 821, 6.IX.1976, bt. (SP); km 115, N.L. Menezes 823, 1.III.1977, bt. (SP); km 100, G. Martinelli 4363, 26.IV.1978, fr. (RB); próximo ao entroncamento Conceição do Mato Dentro - Morro do Pilar, G. Martinelli 4381, 27.IV.1978, fr. (HB); km 114, M.G.L. Wanderley CFSC 5755, 2.XI.1978, bt. (SP); km 114, N.L. Menezes et al. CFSC $5900 \mathrm{e}$ CFSC 5901, 19.XII.1979, fl. (SP); km 111-112, G. Martinelli et al. 11357, 26.I.1986, fl., fr. (SPF, RB); km 109, A. Costa \& T. Wendt 77, 1.II.1987, fr. (RB); Serra do Cipó, P.I.S. Braga s.n., IV.1990, fl. (BHCB 17176); 7 km NE de Cardeal Mota, caminho para Conceição do Mato Dentro, M.M. Arbo et al. 4588, 8.II.1991, fl. (SPF); $12 \mathrm{~km} \mathrm{NE} \mathrm{de} \mathrm{Cardeal} \mathrm{Mota,} \mathrm{caminho} \mathrm{para}$ Conceição do Mato Dentro, M.M. Arbo et al. 4699, 9.II.1991, fr. (SPF); região da canela de ema gigante, M. Pereira et al. 892, 25.VIII.1992, fr. (BHCB); km 125, J.V. Coffani-Nunes 21, 19.I.1993, fl. (SPF); Parque Nacional Serra do Cipó, J.V. Coffani-Nunes 32, 13.III.1993, fl. (SPF); idem, J.V. Coffani-Nunes 34, 14.III.1993, fr. (SPF); Parque Nacional Serra do Cipó, J.V. Coffani-Nunes 43, 2.V.1993, fr. (SPF); cachoeira do Rio Capivara, R.C. Forzza et al. 204, 14.II.1996, fl. (SPF); córrego GrandeBandeirinha, R.C. Forzza et al. 328, 21.X.1997, fl. (SPF); $1 \mathrm{~km}$ ao sul da estátua do Juquinha, L.M. Versieux \& N.L. Menezes 441, 22.V.2007, fr. (SP). Serra do Cipó, Vaccaria, M.B. Foster \& R. Foster 621, 12.VII.1940, fr. (SP); entre os km 131-138, A.P. Duarte 1982, 3.XII.1949, fl. (RB); Serra do Cipó, E.P. Heringer \& A. Castellanos 6150, 5.II.1958, fr. (HB, UB); E.P. Heringer \& A. Castellanos s.n., 8.XI.1958, fr. (HB 32878, US); E.P. Heringer s.n., 12.XI.1959, bt. (SP 78002); P.I.S. Braga, 3.IV.1993, fr. (BHCB); km 115, H.S. Irwin et al. 20471, 19.II.1968, fl. (UB).

Espécie com maior número de registros feitos na Serra do Cipó, bem característica pela roseta estreita e folhas densamente cinéreo-lepidotas. Ocorre como rupícola ou epífita, sendo que em um estudo sobre as epífitas que crescem sobre Vellozia piresiana L.B.Sm. na Serra do Cipó, $V$. oligantha foi a mais abundante (Werneck \& Espírito-Santo 2002). Em alguns casos ocorrem 
brotamentos na inflorescência conhecidos como prolificação ou falsa-viviparidade (Bell 2008). Pode ser considerada indicadora de vegetação de campo rupestre, ocorrendo na Cadeia do Espinhaço e também na Serra da Canastra, no sudoeste de MG. Encontrada em flor na Serra do Cipó no período de novembro a março.

4.9. Vriesea piscatrix Versieux \& Wand., Hoehnea 36(3): 455. 2009.

Fig. 5 H-P, 6 K-M

Epífita, ca. $25 \mathrm{~cm}$ compr. Roseta infundibuliforme. Folhas densamente cinéreo-lepidotas e ambas as superficies, canaliculada, subcoriácea; bainha $6,5-8 \mathrm{~cm}$ compr., 4-5,2 cm larg., oval; lâmina 15-19 cm compr., 1,5-2 cm larg., triangular, recurvada, ápice agudo. Escapo ca. $30 \mathrm{~cm}$ compr. Brácteas do escapo 5,5-6 cm compr., ca. 1,5 cm larg., oblongo-lanceoladas, inconspicuamente aristadas, vermelho-rosadas com ápice esverdeado, imbricadas. Inflorescência ca. $30 \mathrm{~cm}$ compr., simples ou composta, com até 5 ramificações, pêndula. Brácteas florais 3,1-4,2 cm compr., 1,7-2,3 cm larg., vermelho-rosadas com o ápice verde. Flores dísticas; sépalas ca. $2,6 \mathrm{~cm}$ compr., ca. $1 \mathrm{~cm}$ larg., elípticas, verde-claras; pétalas 3,8-4,2 cm compr., ca. 0,7 cm larg., oblongas, ápice obtuso, amarelas; estames ca. 4,5 cm, exsertos; estigma ca. 2 mm diâm. Cápsula e semente não vistas.

Material examinado: Minas Gerais, Santana do Riacho, Serra do Cipó, capão de mata em campo rupestre, $19^{\circ} 09^{\prime} 30.5$ 'S, 43' 31 '0.78'W, 1300 m.s.m., M.G.L. Wanderley et al. 2475, 10.XII.2005, fl. (NY, RB, SP).

A espécie foi descrita recentemente (Versieux \& Wanderley 2009) e é próxima de $V$. guttata, por partilhar morfologia floral semelhante, inflorescência pêndula e possuir folhas com pequenas máculas arroxeadas acima da bainha. Entretanto a forma triangular com ápice agudo e o denso indumento da lâmina foliar (vs. lâmina ligulada, esparsamente lepidota), a inflorescência que pode ser simples ou composta (vs. simples), o maior espaçamento entre as flores e as brácteas florais não-pulverulentas presentes na nova espécie facilitam sua distinção de $V$. guttata. Além disso, as folhas em $V$. piscatrix apresentam poucas máculas arroxeadas acima da bainha, uma ou duas nervuras proeminentes e a lâmina é levemente suculenta. Em $V$. guttata, as folhas são densamente maculadas de roxo em toda a sua extensão, não apresentam nervuras proeminentes nem são levemente suculentas. Essa espécie é conhecida de apenas um capão de mata no topo da Serra do Cipó, onde cresce como epífita acima de $5 \mathrm{~m}$ do solo. Apresenta um aspecto geral delicado e ornamental.

4.10. Vriesea schwackeana Mez in C.DC., Monogr. phan. 9: 590. 1896.

Vriesea monacorum L.B.Sm., Arq. Bot. Estado São Paulo 1: 119, t. 127. 1943. syn. nov.

Fig. 5 Q-S

Epífita, ca. 0,8 cm compr. Folhas 47-55 cm compr., 3,8-4.4 cm larg., lineares; bainha 6,5-7,5 cm larg., castanho-arroxeada; lâmina verde, ápice obtuso, com mucro de ca. $2 \mathrm{~mm}$. Escapo
40-50 cm compr. Brácteas superiores do escapo 4,5-6,5 cm compr., 2,5-4 cm larg., maiores que os entrenós, largo-ovais, ápice arredondado, mucronado, vermelho a rosadas, raramente amareladas na base, eretas. Inflorescência $30-50 \mathrm{~cm}$ compr., ca. $20 \mathrm{~cm}$. diâm., composta, com até 15 ramos patentes, 8-12 floridos, ereta. Brácteas florais 2,5-2,9 cm compr., 2-2,2 cm larg., se igualando ou maiores que as sépalas, largo-ovais, dísticas, vermelhas, lisas ou carenadas para o ápice. Flores dísticas; sépalas 2,2-2,6 cm compr., 6-8 $\mathrm{mm}$ larg., elípticas, amarelo-esverdeadas, geralmente carenadas para o ápice; pétalas ca. $3 \mathrm{~cm}$ compr., ca. $8 \mathrm{~mm}$ larg., liguladas, amarelas; estames inclusos. Cápsula 3,2-4,5 cm compr.

Material examinado: Minas Gerais, Jaboticatubas, Serra do Cipó, $R$. Reitz 7876, 22.V.1975, fr. (HBR).

Material adicional examinado: Minas Gerais, Araponga, Parque Estadual da Serra do Brigadeiro, C.C. Paula 1002, 23.X.1994, fl. (VIC). Encosta Norte do Monte Boavista, serra da Conceição (serra Boa Vista), $N$. Hensold et al. CFCR 2894, 6.III.1982, fr. (SPF). Ouro Preto, serra de Ouro Preto, C.A.W. Schwacke 9209, 14.II.1893, fl. (B, RB); Parque Estadual do Pico do Itacolomi, trilha para o Matipozinho, C.C. Paula \& A. Goldschmidt s.n., 11.II.1999, fl. (VIC 26454). Santa Bárbara, Caraça monastery, 1500 m.s.m., M.B. Foster \& R. Foster 693, VI.1940, fr. (GH, US; holótipo de V. monacorum). São Gonçalo do Rio Preto, Parque Estadual do Rio Preto, P.L. Viana et al. 1256, 5.XII.2003, fl. (BHCB); Parque Estadual do Rio Preto, P.L. Viana et al. 1772, 10.V.2004, fr. (BHCB).

Vriesea schwackeana foi descrita por Mez (1896), homenageando o botânico alemão C.A.W. Schwacke, que coletou várias Bromeliaceae no sul da Cadeia do Espinhaço. O tipo é da Serra de Ouro Preto, a 1500 m.s.m. Smith (1943) descreveu o taxon Vriesea monacorum (monacorum $=$ dos monges, alusão aos padres Vicentinos do Caraça), a partir de uma coleção de M.B. Foster e R. Foster n ${ }^{\circ} .693$ proveniente do mosteiro do Caraça (Serra do Caraça, MG), a 1500 m.s.m. Tal coleção encontra-se em estágio avançado de frutificação, entretanto Smith (1943) afirma que essa espécie seria bem caracterizada por suas brácteas escapais foliáceas, brácteas primárias curtas e ramos da inflorescência patentes e com brácteas florais carenadas. Versieux \& Wendt (2006) chamam a atenção para as similaridades entre $V$. schwackeana e $V$. monacorum, indicando a possibilidade de sinonimização. Ao se comparar as informações contidas nos protólogos de ambas as descrições ficam evidentes as similaridades entre esses dois taxa, que somadas às características observadas nos tipos e no habitat, além da proximidade geográfica entre as serras de Ouro Preto e do Caraça, subsidiam a nova sinonímia aqui proposta. Trata-se de uma espécie endêmica de Minas Gerais, com ocorrências para as serras do Espinhaço e Mantiqueira. Os materiais citados por Smith \& Downs (1977) para o Estado de São Paulo são tratados por Costa et al. (2007) como algo distinto, possivelmente relacionado à $V$. incurvata Gaudich. Na Serra do Cipó, Vriesea schwackeana parece ser uma espécie rara, com apenas um registro antigo. Foi coletada em frutos em julho e em outras áreas de MG, em flores entre dezembro e fevereiro. 


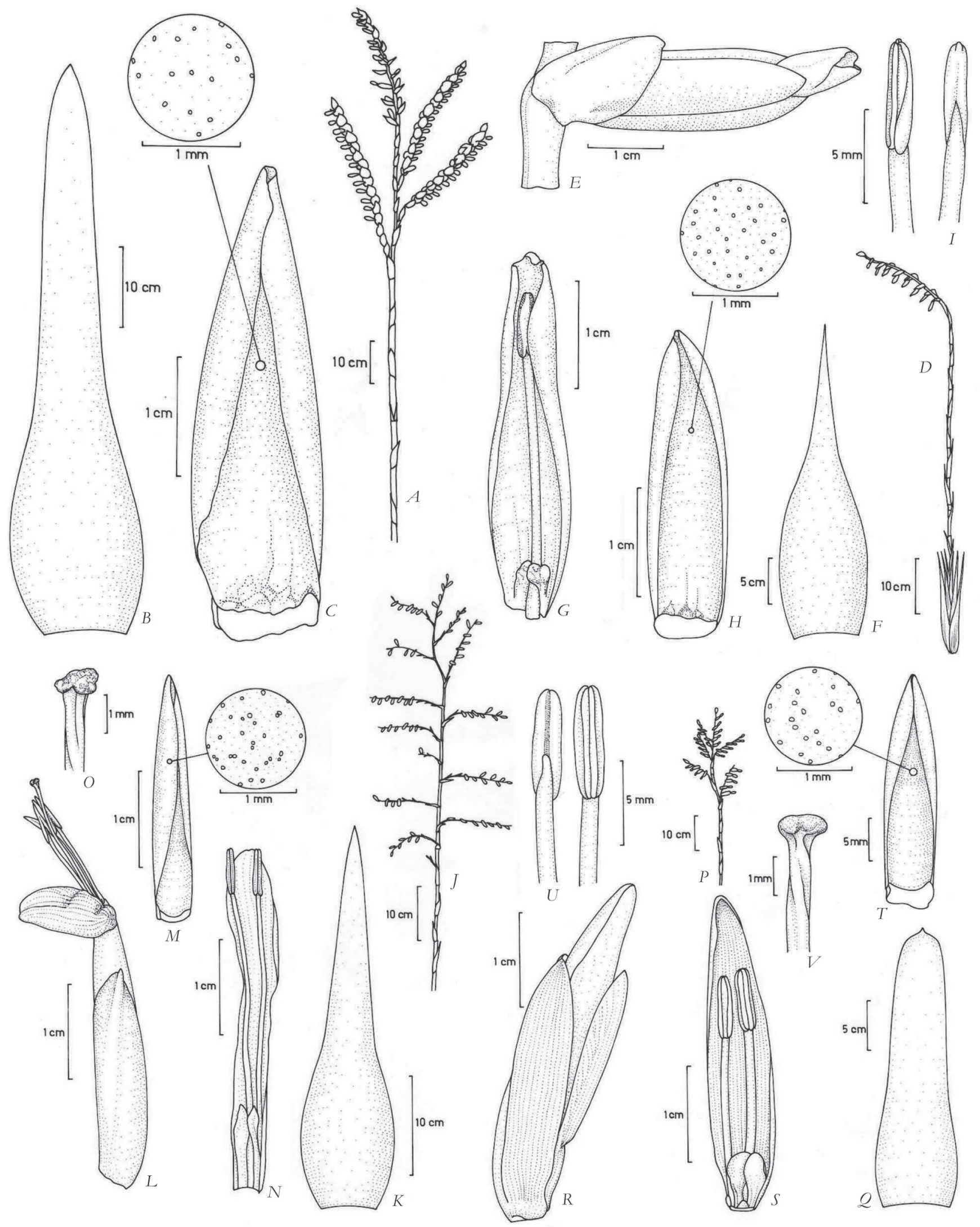

Fig. 4. A-C. Vriesea hoehneana. A. Inflorescência, B. Folha, C. Sépala. D-I. V. oligantha. D. Hábito, E. Flor, F. Folha. G. Pétala, H. Sépala, I. Antera (ventral e dorsal). J-O. V. segadas-viannae. J. Inflorescência, K. Folha, L. Flor, M. Sépala, N. Pétala, O. Estigma. P-V. V. stricta. P. Inflorescência, Q. Folha, R. Botão floral, S. Pétala e estames imaturos, T. Sépala, U. Anteras (dorsal e ventral), V. Estigma. [A-C Coffani-Nunes 33, D-I Coffani-Nunes 32, J-O CFSC 12879, P-V, Coffani-Nunes 17]. 

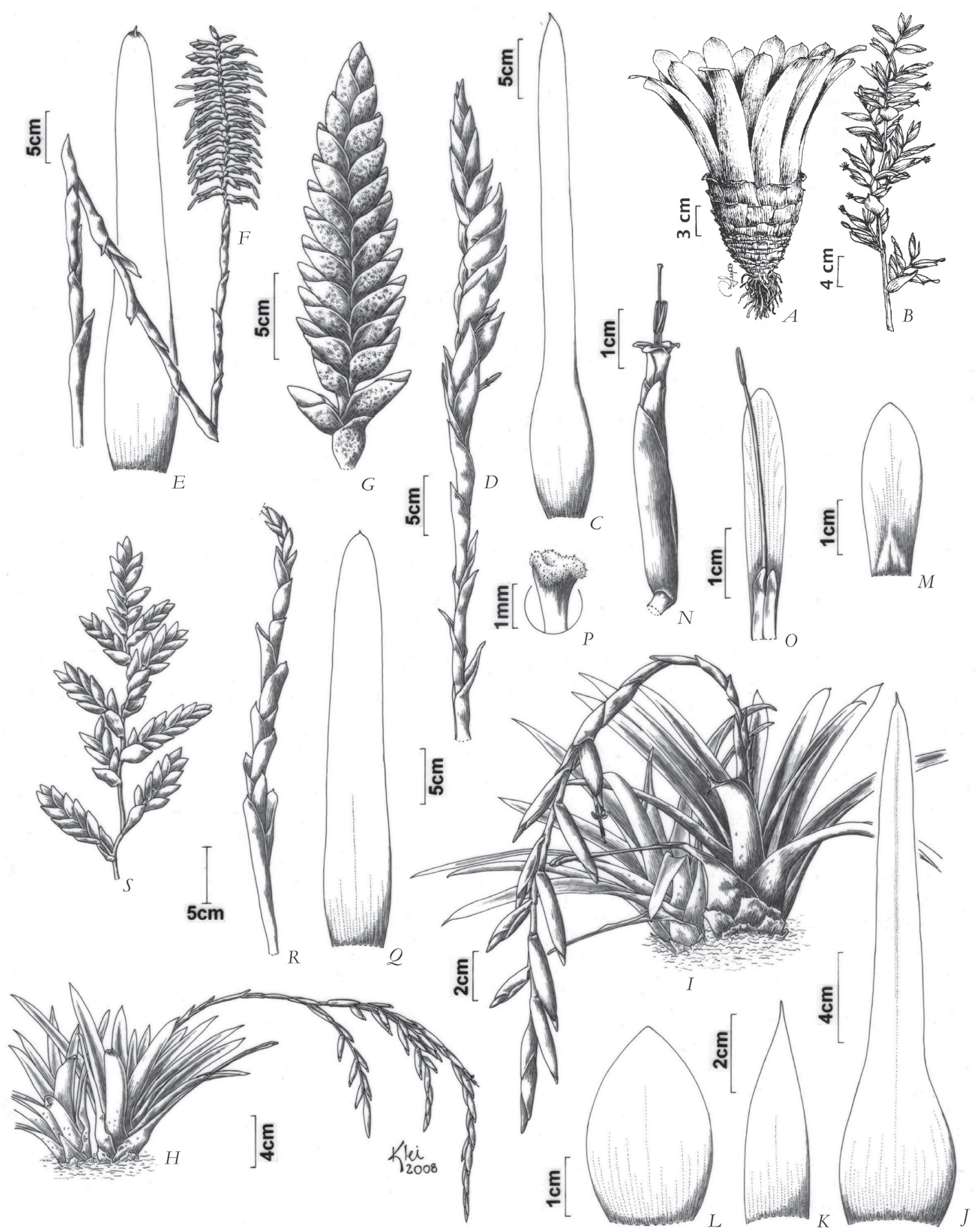

Fig. 5. A-B. Vriesea friburgensis. A. Roseta. B. Inflorescência. C-D. Vriesea longicaulis. C. Folha. D. Inflorescência. E-G. Vrisea aff. minor. E. Folha. F. Inflorescência. G. Detalhe de uma inflorescência em botões. H-P. Vriesea piscatrix. H-I. Hábito de indivíduos com inflorescência composta e simples. J. Folha. K. Bráctea escapal. L. Bráctea floral. M. Sépala. N. Flor. O. Pétala com estame antipétalo. P. Estigma do tipo lâmina-convoluta. Q-S. Vriesea schwackeana. Q. Folha. R. Escapo. S. Inflorescência. [A-B CFCR 9003, C-D, Wanderley 2556, E-G Mota 2170, H-P Wanderley 2475, Q-S Schwacke 9209]. 
4.11. Vriesea segadas-viannae L.B.Sm., Smithsonian Misc. Collect. 126(1): 35. 1955.

Fig. $4 \mathrm{~J}-\mathrm{O}$.

Epífita, 0,8-1,2 m compr. Folhas 29-40 cm compr., 3,5$5 \mathrm{~cm}$ larg., lanceoladas; bainha $14-16 \mathrm{~cm}$ compr., $6,7-8 \mathrm{~cm}$ larg., elíptica, castanha abaxialmente, roxa adaxialmente; lâmina verde, com manchas purpúreas para o ápice, ápice agudo. Escapo 23-62 cm compr. Brácteas superiores do escapo 4,3-5,6 cm compr., 1,5-2,7 cm larg., ovais-acuminadas, eretas, menores que os entrenós. Inflorescência $28-45 \mathrm{~cm}$ compr., composta, laxa, glabra, ereta; ramos (9-)13-20 cm de compr., (3-)5-8-floridos, (2-)6-15, levemente encurvados, 1-2 brácteas estéreis na base. Bráctea primária igual às do escapo, gradualmente menores; brácteas florais 1,7-2,3 cm compr., ca. $1 \mathrm{~cm}$ larg., menores que as sépalas na antese, oblongas, acuminadas, membranáceas. Flores dísticas; sépalas 1,6-2,5 cm compr., 0,8-1 cm larg., amarelas; pétalas 3,7 cm compr., 0,4-0,6 cm larg., amarelas; estames exsertos. Cápsula ca. 4 cm compr.

Material examinado: Minas Gerais, Congonhas do Norte, Serra Talhada (setor nordeste da Serra do Cipó), J.R. Pirani et al. 5167, 19.I.2004, fl. (SPF). Jaboticatubas, Serra do Cipó, M.B. Foster \& R. Foster 635, 12.VII.1940, fr. (SP); Palácio, 1200 m.s.m., L.B. Smith et al. 6755, 28.IV.1952, fr. (R, US); Serra do Cipó, 1200 m.s.m., R. Reitz 7857 , 22.V.1975, fr. (HBR, SP). Santana do Riacho, Serra do Cipó, Rodovia Belo Horizonte-Conceição do Mato Dentro, km 124, J.V.C. Nunes CFSC 12879, 26.X.1991, fr. (SPF); afloramento a $1 \mathrm{~km}$ ao sul da estátua do Juquinha, L.M. Versieux \& N.L. Menezes 440, 22.V.2007, fr. (SP). Serra do Cipó, J. Badini \& H.L. Mello-Barreto s.n., 1938, fr. (OUPR 13875).

Em 1952 Lyman Smith esteve coletando na Serra do Cipó juntamente com o botânico e ecólogo Fernando SegadasVianna. Smith coletou um exemplar de Vriesea epífita que se encontrava em frutificação e o descreveu como uma nova espécie, V. segadas-viannae. Esse táxon permaneceu por longo tempo como uma espécie pouco conhecida, referida apenas pela coleção-tipo, formando um complexo de espécies com V. vagans e com $V$. procera e suas variedades heterotípicas (Versieux \& Wendt 2006). Durante este levantamento encontramos vários espécimes com características muito semelhantes às do tipo de $V$. segadas-viannae, porém sempre com inflorescências maiores e mais ramificadas. Entretanto, as características das folhas e o tamanho e a fina textura das brácteas florais, assim como o tamanho das cápsulas e sementes indicam que, apesar da variação observada na inflorescência, trata-se de apenas uma espécie desse complexo, com ocorrência na Serra do Cipó. Estudos mais abrangentes são necessários para se entender se $V$. segadas-viannae corresponde a um novo sinônimo de $V$. procera ou $V$. vagans, entretanto não foi observado em nenhum material da Serra do Cipó a formação de estolhos, característicos do último táxon. São plantas de inflorescência laxa com ramos muito delgados e flores amarelas bem espaçadas, em geral com bordos das folhas levemente ondulados e bainhas arroxeadas in vivo. Ocorre frequentemente em matas de galeria ou como epífita em moitas de Lychnophora ou Podocarpus em área de campo rupestre nos trechos de maior altitude. Observada em flores em janeiro e em frutos entre abril e julho.

4.12. Vriesea stricta L.B.Sm., Arq. Bot. S. Paulo 2(1): 122, t. 133. 1943.

Fig. 4 P-V, 6 N-O

Rupícola, $30-50 \mathrm{~cm}$ compr. Folhas $26,5-36 \mathrm{~cm}$ compr., 5,5-7 cm larg., liguladas, eretas; bainha 10-15 cm compr., 7,5-9,2 cm larg., castanho-arroxeada; lâmina verde, levemente arroxeada para o ápice, ápice mucronado ou mucronulado. Escapo 19$34 \mathrm{~cm}$ compr. Brácteas superiores do escapo (1,5-)2,5-4 cm compr., 1,8-2,5 cm larg., menores a maiores que os entrenós, oval-lanceoladas ou oblongo-lanceoladas, mucronadas, eretas. Inflorescência 14-26 cm compr., composta, glabra, ereta; ramos 6-10(-14) cm compr., 4-18-floridos, (3)4-9. Bráctea primária semelhante às do escapo. Brácteas florais 1,6-2,3 cm compr., 1-1,5 cm larg., menores que as sépalas, ovais, amarelas. Flores dísticas passando a secundas; sépalas 2,4-2,8(-3,2) cm compr., 0,6-1,3 cm larg., oblongo-elípticas, amarelas; pétalas 2,9-4,3 cm compr., 0,8-1,1 cm larg., oblongas, ápice obtuso, amarelas; estames exsertos.

Material examinado: Minas Gerais, Conceição do Mato Dentro, Parque Natural Municipal do Ribeirão do Campo, R.C. Mota 1865, 13.XI.2002, fl. (BHCB); alto da cachoeira do Tabuleiro, L.M. Versieux et al. 258, 22.XII.2005, fr. (SP). Jaboticatubas, Serra do Cipó, J. Badini \& H. Mello-Barreto s.n., 1938, fr. (OUPR). Santana do Riacho, Serra do Cipó, Rodovia Belo Horizonte-Conceição do Mato Dentro, km 132, A.B. Joly CFSC 3681, 4.XI.1972, fl. (SP, UEC); idem, km 138, M.G.L. Wanderley CFSC 5554, 14.VIII.1979, bt. (SP); Serra do Cipó, M.G.L. Wanderley et al. 216, 217 e 219, 5.VIII.1980, fl. (SP); idem, km 125, N. Hensold et al. CFSC 7731, 7.XII.1981, fl. (SPF, SP); idem, km 126, J.D.P. Oliveira et al. CFSC 9072, 23.X.1982, fl. (SPF); idem, km 123-124, atrás da casa do IBDF, M.G.L. Wanderley \& M.G. Sajo 1976, 24.XI.1991, fr. (SP); Alto do Palácio, km 126, J.V. Coffani-Nunes 17, 17.X.1992, fl. (SPF); afloramento quartzítico em frente ao condomínio Solar do Palácio, L.M. Versieux et al. 301, 8.X.2006, fl., fr. (SP). Serra do Cipó, J. Vidal 5992, II.1953, fr. (R).

Espécie com distribuição restrita, endêmica das áreas mais elevadas da Serra do Cipó. Vriesea stricta assemelhase à $V$. minarum L.B.Sm., espécie endêmica das serras do Quadrilátero Ferrífero e em menor grau, à V. densiflora Mez, espécie endêmica do pico do Itambé e do Parque Estaudual do Rio Preto e Vriesea cacuminis, endêmica da Serra da Mantiqueira (Versieux \& Wendt 2006; 2007). Observou-se durante o trabalho de campo que os botões florais dísticos tornam-se secundos na antese. Essa mesma característica associada à inflorescência mais densa e com maior número de ramos permite a separação deste taxon de $V$. minarum. Outras características vegetativas úteis na separação desses taxa são as médias obtidas para a largura da lâmina foliar $(4,5 \mathrm{~cm}$ em $V$. minarum vs. $6,8 \mathrm{~cm} V$. stricta), comprimento da bainha (11 vs. $15,5 \mathrm{~cm})$ e a largura da bainha $(6,5$ vs. $9,2 \mathrm{~cm})$ (L.M. Versieux, dados não publicados). Vriesea stricta floresce nos meses de agosto a dezembro. 

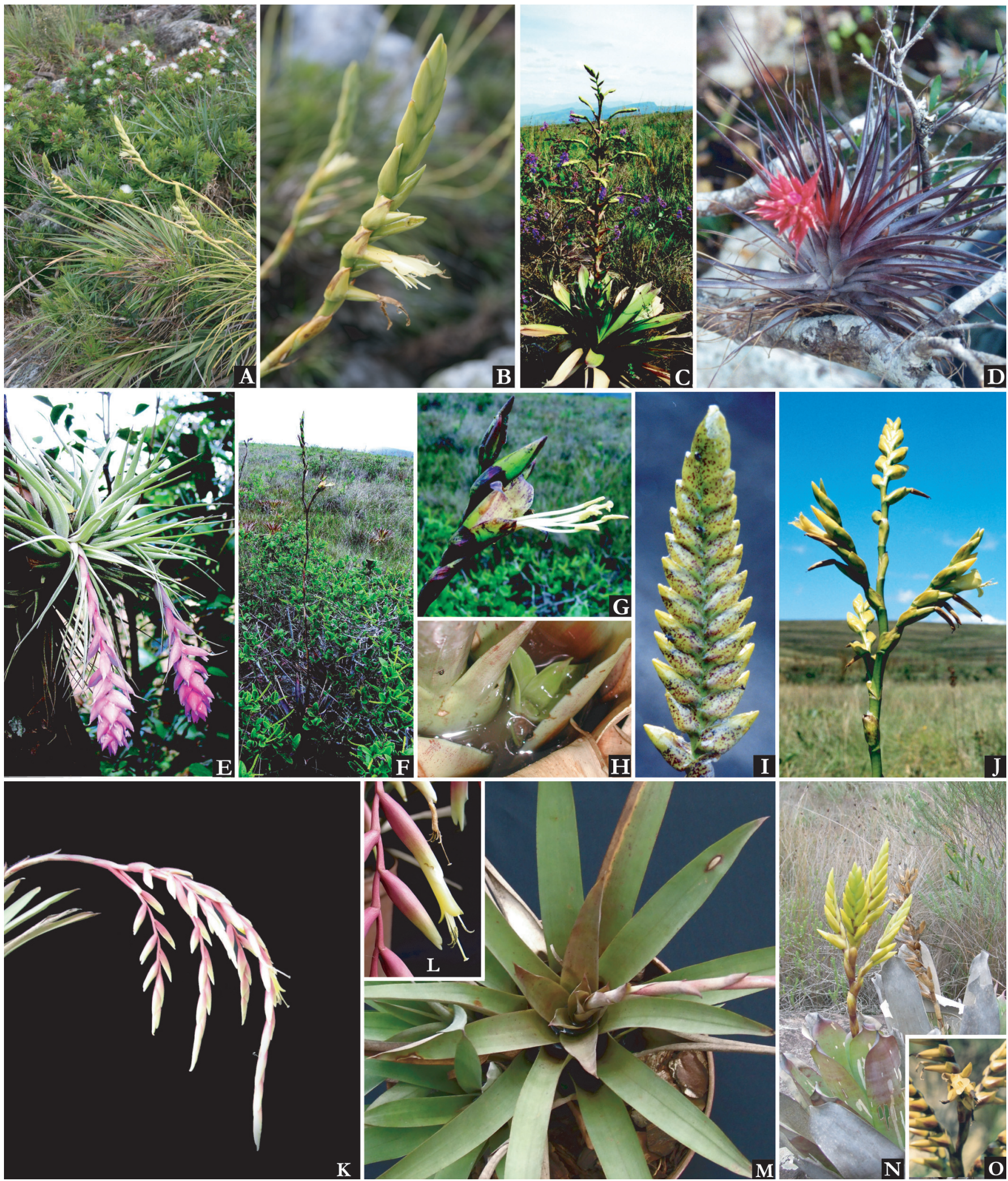

Fig. 6. A-B. Alcantarea hatschbachii. A. Touceira com indivíduos floridos. B. Detalhe da inflorescência, com flores danificadas por herbivoria. C. Alcantarea turgida, indivíduo com folhas verdes. D. Tillandsia geminiflora, Hábito. E. Tillandsia stricta, Hábito. F-H. Vriesea atropurpurea. F. Hábito, G. Detalhe da flor, H. Brotamento axilar. I. Vriesea aff. minor, Inflorescência jovem. J. V. hoehneana, Inflorescência. K-M. Vriesea piscatrix. K. Inflorescência, L. Detalhe da flor, M. Roseta, N-O. Vriesea stricta, M. Hábito, N. Detalhe das flores secundas. [A-B. Zappi 2599, C. Versieux 474, D. Mota 1840, E. RPPN Ermo das Gerais, F-H Versieux 296, I-J. Parque Natural Municipal do Ribeirão do Campo, K-M. Wanderley 2475. N-O Versieux 301, Fotos: L.M. Versieux, exceto A-B, W. Milliken]. 


\section{Agradecimentos}

Os autores agradecem, especialmente, à Emiko Naruto (in memoriam) pela elaboração da maioria dos desenhos e, também, aos ilustradores Klei Sousa, Carmem Fidalgo, Parecis Morato e Rogério Luppo. Ao IBAMA pelas autorizações de coleta e ao Dr. Ademir Reis e à Sra. Zilda Duchamps, do Herbário Barbosa Rodrigues (HBR), pela doação de duplicatas importantes. À Dra. Daniela Zappi e ao Dr. William Milliken por fornecerem informações e gentilmente cederem as fotos da Alcantarea hatschbachii no habitat. Aos revisores anônimos pelos comentários feitos ao manuscrito. M.G.L. Wanderley e J.R. Pirani agradecem ao $\mathrm{CNPq}$ pelo apoio às suas pesquisas por meio de bolsas de produtividade.

\section{Referências}

BARFUSS, M. H. J., SAMUEL, R., TILL, W. \& STUESSY, T. F. 2005. Phylogenetic relationships in subfamily Tillandsioideae (Bromeliaceae) based on DNA sequence data from seven plastid regions. Amer. J. Bot. 92: 337-351.

BELL, A. 2008. Plant form. An illustrated guide to flowering plant morphology. Ed. 2. Timber Press. Portland.

COSTA, A. F., WANDERLEY, M.G.L. \& MOURA, R.L. 2007. Vriesea Lindl. In M.G.L. Wanderley, G.J. Shepherd, T.S. Melhem \& A.M. Giulietti (eds) Flora fanerogâmica do Estado de São Paulo. Instituto de Botânica. São Paulo, vol. 5, p. 126-155, tabs. 23-29.

FORZZA, R.C. \& WANDERLEY, M.G.L. 1998. Flora da Serra do Cipó, Minas Gerais: Bromeliaceae - Pitcairnioideae. Bol. Bot. Univ. São Paulo 17: 255-270.

GIULIETTI, A.M., MENEZES, N.L., PIRANI, J.R., MEGURO, M. \& WANDERLEY, M.G.L. 1987. Flora da Serra do Cipó, Minas Gerais: caracterização e lista das espécies. Bol. Bot. Univ. São Paulo 9: 1-151.
MARTINELLI, G., VIEIRA, C.M., GONZALEZ, M., LEITMAN, P., PIRATININGA, A., COSTA, A.F. \& FORZZA, R.C. 2008. Bromeliaceae da mata atlântica brasileira: lista de espécies, distribuição e conservação. Rodriguésia 59: 209-258.

MEZ, C. 1891-1894. Bromeliaceae. In C.F.P. Martius, A.G. Eichler \& I. Urban (eds) Flora brasiliensis. Frid. Fleischer. Lipsiae, vol. 3, pars 3, p. 173-634 p., tabs. 51-114.

MEZ, C. 1896. Bromeliaceae. In A.C.P. de Candolle (ed.) Monographiae phanerogamarum. Masson. Paris, vol. 9, p. 1-990.

REITZ, R. 1983. Bromeliáceas e a Malária-Bromélia Endêmica. In R. Reitz (ed.) Flora Ilustrada Catarinense. Herbário Barbosa Rodrigues. Itajaí, parte I, fasc. Brom. p. 1-808.

RIBEIRO, O.B.C., PAULA, C.C. \& GUARÇONI, E.E. 2009. A new Vriesea species from Serra do Cipó National Park, Minas Gerais, Brazil. J. Bromeliad Soc. 59: 7-11.

SMITH. L.B. 1943. Bromeliáceas novas ou interessantes do Brasil - II. Arquivos de Botânica do Estado de São Paulo 1: 102-122, tab. 101-134.

SMITH, L.B. \& DOWNS, R.J. 1974. Pitcairnioideae (Bromeliaceae). Fl. Neotrop. Monogr. 14: 1-658.

SMITH, L.B. \& DOWNS, R.J. 1977. Tillandsioideae (Bromeliaceae). Fl. Neotrop. Monogr. 14: 663-1492.

TILL, W. 2000. Tillandsioideae. In D. H Benzing, (ed.) Bromeliaceae: profile of an adaptive radiation. Cambridge University Press, Cambridge, United Kingdom, p. 555-571.

VERSIEUX, L.M. \& WANDERLEY, M.G.L. 2009. Vriesea piscatrix (Bromeliaceae): uma nova epífita da Serra do Cipó, Minas Gerais, Brasil. Hoehnea 36: 455-458.

VERSIEUX, L.M. \& WENDT, T. 2006. Checklist of Bromeliaceae of Minas Gerais, Brazil, with notes on taxonomy and endemism. Selbyana 27: 107-146.

VERSIEUX, L.M. \& WENDT, T. 2007. Bromeliaceae diversity and conservation in Minas Gerais, Brazil. Biodiversity and Conservation 16: 2989-3009.

WERNECK, M.S. \& ESPÍRITO-SANTO, M.M. 2002. Species diversity and abundance of vascular epiphytes on Vellozia piresiana in Brazil. Biotropica 34: 51-57. 